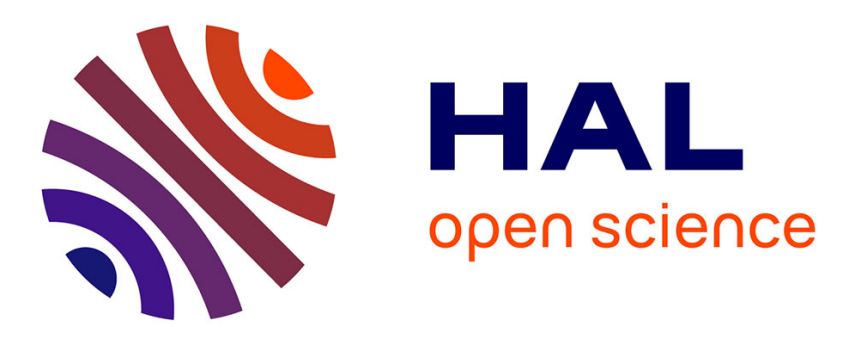

\title{
Repeated fluid expulsions during events of rapid sea-level rise in the Gulf of Lion, western Mediterranean Sea
}

Aurélien Gay, Thibault Cavailhès, Dominique Grauls, Bruno Marsset, Tania Marsset

\section{To cite this version:}

Aurélien Gay, Thibault Cavailhès, Dominique Grauls, Bruno Marsset, Tania Marsset. Repeated fluid expulsions during events of rapid sea-level rise in the Gulf of Lion, western Mediterranean Sea. Bulletin de la Société Géologique de France, 2017, 188 (4), pp.24. 10.1051/bsgf/2017190 hal-02965039

\section{HAL Id: hal-02965039 \\ https://hal.science/hal-02965039}

Submitted on 14 Oct 2020

HAL is a multi-disciplinary open access archive for the deposit and dissemination of scientific research documents, whether they are published or not. The documents may come from teaching and research institutions in France or abroad, or from public or private research centers.
L'archive ouverte pluridisciplinaire HAL, est destinée au dépôt et à la diffusion de documents scientifiques de niveau recherche, publiés ou non, émanant des établissements d'enseignement et de recherche français ou étrangers, des laboratoires publics ou privés. 
A. Gay et al.

\title{
Repeated fluid expulsions during events of rapid sea-level rise in the Gulf of Lion, western Mediterranean \\ Sea.
}

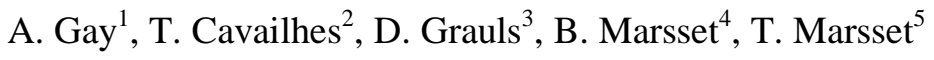 \\ 1: Géosciences Montpellier, Université de Montpellier 2, Place Eugène Bataillon, 34095 \\ Montpellier, France \\ 2: EPOC, Université de Bordeaux, Site de Talence, 33615 Pessac, France \\ 3: Consulting , 9 rue O'Quin 64000, Pau, France \\ 4: IFREMER-EDROME, Géosciences Marines, 29280, Plouzané, France \\ 5: IFREMER, Géosciences Marines, 29280, Plouzané, France
}

Corresponding address: aurelien.gay@gm.univ-montp2.fr

Keywords: pockmark, fluid overpressure, cycles, cone deformation

Short Title: Repeated fluid expulsion in the Gulf of Lion

Number of words: 8168

\section{SUMMARY}

Based on a High-Resolution 3D seismic block acquired in the Gulf of Lion in 2004-2005 we investigated fluid pipes and pockmarks on the top of the interfluve between the Hérault canyon and the Bourcart canyon both created by turbidity currents and gravity flows from the shelf to the deep basin in the north-western Mediterranean Sea. Combining the geometry of the potential fluid pipes with the induced deformation of surrounding sediments leads then to the ability to differentiate between potential fluid sources (root vs source) and to better estimate the triggering mechanisms (allochtonous vs autochtonous cause). We linked together a set of derived attributes, such as Chaos and RMS amplitude, to a three dimensional description of pipes along which fluids may migrate. As previously shown in other basins, the induced deformation, creating cone in cone or V-shaped structures, may develop in response to the fluid pipe propagation in unconsolidated sediments in the near surface. The level at the top of a cone structure is diachronous. It means that stratigraphic levels over this surface are deformed at the end of the migration. They collapse forming a depression called a pockmark. These pipes are the result of repeated cycles of fluid expulsion that might be correlated with rapid sea-level rise instead of sediment loading. The most recent event (MIS 2.2 stage) has led to the formation of a pockmark on the modern seafloor. It has been used as a reference for calculating the effect of a rapid sea-level rise on fluid expulsion. As all physical and geometrical parameters are 


\section{A. Gay et al.}

constrained, we were able to define that a $+34 \mathrm{~m}$ of sea level rise may account for triggering fluid expulsion from a very shallow silty-sandy layer at $9 \mathrm{~m}$ below seafloor since the last glacial stage. This value is consistent with a sea level rise of about $102 \mathrm{~m}$ during this period. This study shows that the episodic nature of fluid release resulted from hydromechanical processes during sea-level rise due to the interactivity between high pressure regimes and principal in situ stresses.

\section{INTRODUCTION}

Focused fluid migration in marine sediments is a widespread phenomenon which is increasingly gaining attention in the context of environmental discussions, even though it is still not well understood (Berndt, 2005). However, increased data coverage and the advent of new tools in oceanic exploration, such as backscatter imagery, multibeam swath bathymetry maps and 3D seismic data, can provide new evidence of relatively small-scale fluid seep structures on modern continental margins, and can help towards improving our understanding of the underlying processes. Fluid migration in sedimentary basins is an important process because 1) they accumulate into reservoirs that might be of economic interest; 2) the input of greenhouse gases into the ocean/atmosphere system may be an important component of the atmospheric carbon budget (Judd et al., 2002); 3) the fluid expulsion at the seafloor may play a role in potential instabilities on slopes (Prior and Coleman, 1984; Evans et al., 1996; Yun et al., 1999; Cochonat et al., 2002), representing a risk for human activities (Sultan et al., 2001; Elverhøi et al., 2002); and 4) fluid expulsion sites form the basis for a plethora of chemosynthetic benthic ecosystems that play an important role in the deep marine communities (Sibuet, 2003).

Since their initial identification on the Scotian Shelf by King and MacLean (King and MacLean, 1970), pockmarks have been reported repeatedly during offshore hydrocarbon exploration and scientific surveys in various depositional systems at water depths ranging from $30 \mathrm{~m}$ to over 3000 m (for a detailed review see Josenhans et al., 1978; Werner, 1978; Hovland, 1981; Whiticar and Werner, 1981; Hovland and Judd, 1988; Solheim and Elverhoi, 1993; Baraza and Ercilla, 1996; Rollet et al., 2006). They generally appear in unconsolidated, fine grained sediments as cone-shaped circular or elliptical depressions, ranging from a few meters to $800 \mathrm{~m}$ or more in diameter and from $1 \mathrm{~m}$ to 80 $\mathrm{m}$ in depth, and they concentrate in fields extending over several square kilometers. In some cases, they have been identified along straight or circular lines correlated with glaciomarine tills (Josenhans et al., 1978; Whiticar and Werner, 1981; Kelley et al., 1994) suggesting a geological control on focused fluid flow (Eichhubl et al., 2000; Cifci et al., 2003; Gay et al., 2003). In particular, structural surfaces along bedrock (Shaw et al., 1997), salt diapirs (Taylor et al., 2000; Satyavani et al., 2005), faults and faulted anticlines (Boe et al., 1998; Soter, 1999; Vogt et al., 1999; Eichhubl et al., 2000; Dimitrov and Woodside, 2003) create pathways for fluid migration (Nakajima et al., in press). These observations suggest that discontinuities or unconformities are much more effective for fluid migration than a simple diffusive seepage through the sedimentary column (Abrams, 1992; Brown, 2000) and 


\section{A. Gay et al.}

are responsible for focused fluid flow, fluid escape at the seafloor and pockmark development (Abrams, 1992; Orange et al., 1999). The crater-like nature of pockmarks suggests an erosional power of fluid venting (Hovland and Judd, 1988), commonly related to an overpressured buried reservoir of biogenic gases, thermogenic gases, or oil, interstitial water, or a combination of the three. Time varying fluxes may be recorded into seafloor fluid seeps. An integrated study conducted on a giant pockmark of the Lower Congo Basin at $3200 \mathrm{~m}$ water depth has shown that the mineralogical, chemical, and biological facies are clearly related to upward fluid intensity (Gay et al., 2006c).

On the geophysical record, either 2D or 3D seismic data, pipes (or chimneys) are usually imaged as systematic disruptions and/or offset of the reflections within vertical zones, $50-1000 \mathrm{~m}$ wide and up to $1000 \mathrm{~m}$ high (Løseth et al., 2011). They are augmented by observations of amplitude enhancement or dimming. On seismic profiles, the pipe internal structure is characterized by reflections that are bent or offset upward (pull-up effect) or downward (pull-down effect) relative to the host stratigraphy by 20 to $150 \mathrm{~ms}$ TWT. Pipes are interpreted to represent a high-permeable vertical zone called a seal bypass system (Cartwright et al., 2007) caused by high fluid overpressure hydro-fracturing sediments of low permeability (Arntsen et al., 2007; Rodrigues et al., 2009). This geophysical characterization seems actually well constrained in space and time. However, neither the root of a pipe nor the triggering mechanisms are clearly defined. The interpretation of seismic data usually leads to a gap between the final result of fluid remobilization (i.e. fluid pipe and pockmarks recorded at the time of geophysical acquisition) and the physical causes that have triggered fluid migration in the past.

In the following sections, we will investigate fluid pipes and pockmarks located in the Gulf of Lion (Fig. 1). The final aim of this study is to link a set of derived attributes, such as Chaos and RMS amplitude, to a three dimensional description of pipes along which fluids may migrate and the induced deformation of surrounding host sediments. We will show that these pipes are the result of repeated cycles of fluid expulsion. Combining the geometry of the potential fluid pipes with cone-incone deformation structures using High-Resolution 3D seismic leads then to the ability to differentiate between potential fluid sources, root vs source (Gay et al., 2012) and to better estimate the triggering mechanisms (allochtonous vs autochtonous cause).

\section{GEOLOGICAL SETTING}

The HR 3D seismic area lies on the western flank of the Gulf of Lion (GoL) upper continental slope at 250-450 m water depth (Fig. 2). The GoL forms a crescent-shaped passive margin that is characterized by a $70 \mathrm{~km}$ wide continental shelf on the northwest part of the Mediterranean Sea. The Rhone River is the modern major source of sediment to the GoL shelf while other minor fluvial inputs also occur along the coastline (Pont et al., 2002). However, the buildup of the margin was strongly controlled by Quaternary glacial-interglacial sea-level variations (Rabineau et al., 2006; Frigola et al., 2012) and by significant subsidence at the shelf edge that has led to the deposition and 


\section{A. Gay et al.}

preservation of sedimentary bodies and to the incision of numerous canyons mainly oriented NW to SE and N to S (Berné et al., 2001; Baztan et al., 2005). The study area lies between two major canyons, the Bourcart Canyon and the Hérault Canyon (Fig. 2). The canyons display a marked axial incision that is interpreted as the imprint of erosive turbidity current initiated at the canyon head when it was connected to a river during the last sea-level low stand (Baztan et al., 2005). Actually, sediments are transported through the canyons by episodic dense shelf water formation and cascading events (DSWC) (Canals et al., 2006; Palanques et al., 2006; Pasqual et al., 2010; Sanchez-Vidal et al., 2008, 2012; Gaudin et al., 2006).

In situ testing carried out at $300 \mathrm{~m}$ long PRGL 1 (42 $\left.41^{\circ} 23.30^{\prime \prime} \mathrm{N}, 3^{\circ} 50^{\prime} 15.50^{\prime \prime} \mathrm{E}\right)$ and PRGL 2 (42 $50^{\prime} 58.20^{\prime}$ 'N, 339'30.85' 'E) boreholes (Fig. 2), have led to the identification of five main sequences ( $\mathrm{S} 1$ to S5) stacked during the sea-level lowering phases of the last five glacialinterglacial 100-kyr cycles (Basetti et al., 2008). We used as a reference the commonly admitted D3045-50-55-60-64-65-70 relative high sea-levels (Fig. 3), corresponding to each Dansgaard-Oeschger Greenland warm interstadial (Rabineau et al., 2006).

For geotechnical characterization, a continuous cone penetration test unified (CPTU) was performed at sites PRGL1 and PRGL2 (Lafuerza et al., 2008) but we used here only the PRGL1 as it was carried out within the area of HR 3D seismic acquisition. The test was made with a static penetrometer measuring cone resistance $(\mathrm{kPa})$, sleeve friction $(\mathrm{kPa})$ and pore pressure acting on the cone $(\mathrm{kPa})$. Estimation of sediment types based on geotechnical properties was done using the method of soil classification established after Ramsey (2002). All geotechnical data were combined for soil characterization, considering that the pore pressure (u2) is mainly related to the permeability of sediments, whereas the resistance to cone penetration (qt) and the lateral friction (fs) can be directly correlated to a particular lithology (Fig. 3).

The lithologically homogeneous site PRGL1 is characterized by clays interbedded with silty-clays and locally sand to clayey sands (Lafuerza et al., 2008). Units I, III and IV are quite similar in terms of lateral friction (fs). Subunits IIb (from 33 to $36 \mathrm{mbsf}$ ), IIId (70-72 mbsf), and IVd (120 127 mbsf) comprise the reflectors corresponding to discontinuities D63, D60, and D50, which are found to represent intervals of variable thickness characterized by low friction measurements due to increased sand content. The lower unit V corresponds to S3. The rest of the boundaries between the CPTU-based subunits correspond to specific seismic reflectors defining different seismic facies: subunits IIa and IIIc correspond to low-amplitude hemistratified facies; IIIb, IVa, IVb, Va, and Vb to facies of intermediate amplitude; and IIIa, IIIb, and IVc to facies of higher relative amplitude (Lafuerza et al., 2008). Such changes in relative amplitude in the seismic record do correlate well with the CPTU-based geotechnical-stratigraphic divisions. 


\section{A. Gay et al.}

\section{DATA BASE AND PROCESSING}

In 2004-2005 a High Resolution (HR 40-250 Hz) 3D seismic dataset was acquired in the Gulf of Lion over a $8.5 \times 1.6 \mathrm{~km}$ area between the Bourcart canyon and the Hérault canyon (Thomas et al., 2004; Jouet, 2007) (Fig. 2).

The HR3D seismic source consists of small volume air guns (mini-GI gun, $110 \mathrm{~Hz}$ dominant frequency) able to produce a repetitive signal. Two source arrays, $12.5 \mathrm{~m}$ apart, are fired alternately in order to have the cross-line sampling interval for a given number of streamers. Two streamers are deployed $25 \mathrm{~m}$ apart using two eight-meter long rigid bars fixed to the vessel's frame. Each streamer hosts 48 channels, with a $6.25 \mathrm{~m}$ group interval (Thomas et al., 2012). This seismic layout prevents spatial aliasing of dipping events up to $40^{\circ}$ in the in-line direction and $20^{\circ}$ in the crossline direction. Positioning of sources and receivers is determined using the DGPS position and gyrocompass of the vessel, and magnetic compasses from 3 depth controllers along each streamer. Given the accuracy of these sensors and the short length of the streamers (400 meters), receiver positions are calculated within an absolute accuracy of $2 \mathrm{~m}$ at the head of the streamers, to $4 \mathrm{~m}$ at the tail. Source positions are measured to an absolute accuracy of $1 \mathrm{~m}$. Positioning accuracy requirement to allow accurating wavefield reconstruction is $1 / 4$ (where 1 is the dominant wavelength; Gutowski et al. 2008), thus $3.4 \mathrm{~m}$ considering the expected resolution given for the dominant wavelength $(13.5 \mathrm{~m}$ @ $110 \mathrm{~Hz}$ ). As the achieved positioning accuracy is between 2 and $4 \mathrm{~m}$, the resulting resolution is slightly degraded.

Data editing and updating of the fold map are performed at the end of each line to assess the homogeneity of the data and to adjust the acquisition program to acquire additional in-fill lines to cover gaps in the fold map. Considering the relatively shallow water depth on the survey area, additional 2D HR seismic data recorded using longer source-receiver offset (490 m compared to the $375 \mathrm{~m}$ maximum offset of the 3D layout) has allowed to constrain the velocity field within the upper sedimentary layers of interest (Marsset et al., 2012). A two-layer velocity model, $1515 \mathrm{~m} / \mathrm{s}$ for the water column, and a constant gradient of $400 \mathrm{~m} / \mathrm{s}$ increasing for the sediments was then applied to perform 3D stacking following by constant velocity two-pass Stolt time migration. The resulting seismic migrated volume should then reach a lateral resolution close to the 12.5 meters theoretical one. The vertical resolution is around 2.5 meters.

In the following study we derived seismic attributes from the amplitude of the HR 3D migrated dataset. However, free gas and/or carbonate cements have strong effects on the seismic signal and on the seismic amplitude as reflections can be respectively moved down or up. This is commonly attributed to a pull-down or a pull-up effect due to the migration during processing. So, seismic amplitude alone can be difficult to interpret in environments dominated by lateral and vertical fluid migrations through sediments. Due to the vertical pattern of seismic pipes (or chimneys) a typical horizon picking is not accurate to image them in a 3D domain. New tools in the academia and 


\section{A. Gay et al.}

petroleum exploration allow individualizing these chimneys from the 3D block (Gay et al, 2006; Gay et al., 2012):

The "RMS amplitude" $\left(x_{r m s}\right)$ provides a scaled estimate of the trace envelope. It is computed in a sliding tapered window of $N$ samples as the square root of the sum of all the trace values $x_{n}$ squared:

$$
x_{r m s}=\sqrt{\frac{1}{N} \sum_{n-1}^{N} w_{n} x_{n}^{2}}
$$

where $w_{n}$ are the window values.

. The "Chaos attribute" is designed to measure the "lack of organization" in the dip and azimuth estimation method, based on the amplitude of reflectors and their continuity. Vertical and subvertical seismic pipes appear as homogeneous high-amplitude anomalies, ovoid in shape.

High RMS amplitude associated with a high chaotic signal pattern contained within seismic data can directly be related to the presence of fluids and or cements and thus can map hydrocarbon indications in the data and other geologic features which are isolated from background features by amplitude response (Gay et al., 2006, 2007). Alternatively, low RMS amplitude associated with a high chaotic signal pattern is rarely considered in seismic data. It can be used as a good indicator of the deformation of sediments induced by recent fluid motion through sediments, although coherency attribute alone gives only an indication of the deformation (Gay et al. 2012).

\section{RESULTS}

\section{Morphology and structure of seafloor pockmarks}

We identified more than 180 pockmarks in the study area with an average density of 13,2 pockmarks per $\mathrm{km}^{2}$ (Fig. 4). They range from 12,5 m (limit of seismic horizontal resolution) to $180 \mathrm{~m}$ in diameter, and from 4 to $15 \mathrm{~ms}$ TWT in depth with respect to the surrounding seabed. Most of them have a circular to sub-circular shape in plane view. The shaded relief map produced from the 3D seismic data shows that pockmarks are not randomly distributed on the seafloor (Fig. 4). They are mainly concentrated on the crest of a WNW-ESE striking anticline structure corresponding to the interfluves between the Bourcart and the Herault canyons.

About 6 pockmarks, located in the North-East part of the 3D seismic area, are wider than 100 meters. They are aligned parallel to the slope break of the Herault canyon (Fig. 4). The present Herault canyon is the last erosional episode of a series of glacial-interglacial 100-kyr cycles leading to incision-infill cycles. During these successive events, the canyon moved laterally creating a large valley. On the seismic section IL211, these pockmarks are aligned over a steep erosional surface of the paleo-canyon that incises into the upper slope (Fig. 5). As shown in the Lower Congo Basin (Gay et al.; 2007), fluids likely originate from deeper levels where they migrate laterally along dipping permeable stratigraphic units and more vertically along erosional unconformities or faults. 


\section{A. Gay et al.}

In the South-West part of the 3D seismic area, only a few small pockmarks, 10 to 15 meters wide, have been identified (Fig. 4). They lie at the border of a terrace of the Bourcart canyon. They are probably related to a similar fluid migration pathway linked to a buried erosional surface. On the almost flat part of the terrace, no pockmarks have been detected. The infilling of the terrace is made of a succession of aggrading continuous and homogenous amplitude reflections interlayered with localized chaotic facies (Fig. 5). This seismic pattern is typically interpreted as Mass Transport Deposits (MTD's) and they probably come from instabilities on the flank of slope slidding towards the Bourcart canyon. Due to overconsolidation during the deposition process, MTD's are usually considered as an impermeable barrier (Gay et al., 2007b and references therein). Fluids migrate laterally towards the erosional surface where they are then driven upward and may accumulate and/or be expelled at the top of the anticline structure (Gay et al., 2007a).

As most of pockmarks are concentrated on the top of the anticline structure, we focused on this sub-area within the 3D seismic block. Pockmarks imprint the seafloor forming sub-circular depression, and they are often correlated with underlying depressions or amplitude anomalies.

\section{Seismic pipes}

Free gas can easily be interpreted from seismic records because even small amounts of gas within pore space significantly decrease the acoustic impedance of sediments and create anomalies such as acoustic turbidity, enhanced reflections (bright spots, flags) and acoustic blanking (wipe out) (Anderson and Hampton, 1980; Judd and Hovland, 1992; Schroot et al., 2005).

In most basins seismic profiles through pipes show two levels of acoustic anomalies, vertically elongated under the main depression (Gay et al., 2006). The deep anomaly is an inverted cone shape in cross section and it is marked by lower amplitude reflectors and acoustic turbidity. On both sides of this region the bright reflectors shift upward. This pull-up may be due to fluid movement (structural) or to velocity effects caused by hydrate/carbonate cementing within the overlying pipe corresponding to the shallow anomaly. The pipe is ovoid in shape with depressed high-amplitude reflectors considered as a reduction of the seismic velocities (pull-down effects), even if this could be real depressions due to fluid expulsion (ancient pockmarks?). Such acoustic anomalies are also called seismic chimneys and could be indicative of fluid flow from deeper levels (Hovland and Judd, 1988; Judd et al., 1992; Hempel et al., 1994; Heggland, 1997; Tingdahl et al., 2001; Ligtenberg, 2005).

On the seismic section IL211 a 250 ms TWT thick sub-vertical anomaly has been identified (Fig. 5). The pipe is the result of vertically stacked pull-down reflections, from 40 to $200 \mathrm{~m}$ in diameter. The main vertical axis of the pipe (i.e. the lowest part of each downbending reflection) is generally marked by higher amplitudes than the average amplitude along the reflections. The base of the pipe, or the root, seems to be at the D50 stratigraphic reflection. However, a single seismic section gives a partial view of the pipe. On a set of 9 seismic sections crosscutting the pipe (Fig. 6), the IL239 clearly shows that the anomaly starts about $15 \mathrm{~ms}$ TWT above the D45 stratigraphic reflection. The 


\section{A. Gay et al.}

IL219, there is no anomaly detected above or beneath the D50 stratigraphic reflection. On IL2 15 to IL207, the pipe starts from the D50 stratigraphic reflection and propagates upward. High amplitude anomalies within the pipe affect the D60 stratigraphic reflection on IL211 and 215 at about $560 \mathrm{~ms}$ TWT. On IL215, from 475 to $525 \mathrm{~ms}$ TWT, downbending reflections are not continous and they are crosscut by a vertical anomaly characterized by polarity inversions at some points. This typical pattern of a gas charged pipe propagates upward on IL 219 where it reaches the seafloor and connect to the modern pockmark. The bottom of the main depression (i.e. the deepest point of the pockmark compared to the regional seafloor) is located on IL219. However, high amplitude reflections forming a vertically elongated anomaly are still visible on the south flank of the pockmark from IL227 to IL239.

This basic description of seismic anomalies clearly illustrates that a fluid pipe is not only a vertical to sub-vertical conduit. Although seismic sections are commonly used for interpreting fluid pipes, this method cannot be used to characterize all pipes present in a seismic block. A derived attribute, the Chaos attribute, has been calculated and time slices are extracted every $50 \mathrm{~ms}$ from 400 ms to $750 \mathrm{~ms}$ TWT (Fig. 7). The Chaos attribute calculation is based on the amplitude variation and the continuity of reflections. At $400 \mathrm{~ms}$ TWT, the dipping flanks of the major pockmarks, 40 to $200 \mathrm{~m}$ wide, appear with a medium to high amplitude of Chaos. The bottom of the depression is low in amplitude of Chaos, which ismore consistent with surrounding regional sediments. The small pockmarks, 20 to $40 \mathrm{~m}$ wide, are close to the detection limit and they appear as spots of medium to high amplitude of Chaos. At $450 \mathrm{~ms}$ TWT, the time slice crosscut underlying pipes. They are characterized by a ring of medium amplitude of Chaos that does correspond to the area where the reflection starts to bend. The flanks are low in amplitude of Chaos and the axis of the pipe, corresponding to the bottom of the depression, is medium to high in amplitude of Chaos. This pattern would allow discrimination of pipes and ring and of pockmarks and paleo-pockmarks on a vertical section. However, a paleo-pockmark and its associated underlying pipe can be re-used or reactivated by later fluid migration and the geophysical signal might be modified, sometimes even shaded. This is the case from 500 to $750 \mathrm{~ms}$ TWT where rings of medium to high amplitude of Chaos are vertically correlated with spots or pipes of high amplitude of Chaos that appear over these features. This vertical succession of amplitude anomalies shows that pockmarks can be reactivated, leading to the development of a new pipe capped by a new pockmark until the fluid expulsion episode stops.

The large pockmark identified on seismic sections IL207 to IL239 (see Fig. 5) illustrates the vertical succession of amplitude anomalies (Fig. 7). It is marked by flanks of high amplitude of chaos down to $450 \mathrm{~ms}$ TWT. From 500 to $550 \mathrm{~ms}$ TWT the pipe is characterized by a ring of medium amplitude of Chaos. At $600 \mathrm{~ms}$ TWT it transforms into a spot of high amplitude of Chaos. Below 650 ms TWT, no anomaly has been detected, which is consistent with the interpretation of a vertical section showing that the base of the pockmark takes root right beneath the D45 stratigraphic level.

In such an approach, either characterizing a pipe on a vertical section or in time slices using seismic amplitude and Chaos attribute, it is particularly difficult to define the root of each event 


\section{A. Gay et al.}

corresponding to the reactivation. For example, the root accounting for one event can be situated beneath the paleo-pockmark or within the pipe corresponding to the previous event.

\section{Constraining pipe geometry using horizontal dissection}

A new method for characterizing fluid pipes has been recently developed using sandbox models coupled to geophysical analysis (Mourgues et al., 2011, 2012; Gay et al., 2012). Based on the RMS amplitude, 7 levels of the fluid pipe have been identified from the D45 stratigraphic reflection to the seafloor (Fig. 8). About 200 time slices have been extracted. 19 time slices display the same pattern in which the base of a level is marked by a tiny spot of very low RMS amplitude. A ring of low RMS amplitude develops from the base and becomes greater to the top of the interval with an average diameter of 50 to $70 \mathrm{~m}$ for small depressions and an average diameter of $150-250 \mathrm{~m}$ for large depressions.

In a $3 \mathrm{D}$ view, the vertical succession of spots defines a stem and the flanks of the cone refer to as a corolla in a flower structure (Gay et al., 2012). It is interesting to note that the corolla on RMS amplitude is about $20 \%$ larger than the depression identified both on seismic amplitude and Chaos attribute.

\section{DISCUSSION}

In the Gulf of Lion (GoL) margin, western Mediterranean Sea, deltaic forced Regressive Progradational Units (RPUs) stacked on the outer-shelf and upper slope during relative sea-level falls led some authors to describe this margin as a forced regressive system (Posamentier et al., 1992; Tesson et al., 1990, 2000). The significant subsidence rate of the margin, $250 \mathrm{~m} . \mathrm{Myr}^{-1}$ at the shelf edge (Rabineau, 2001), eased the preservation of RPUs in the upper slope, as it was continuously submerged even during pronounced lowstands. These significant subsidence rate allowed preserving the majority of the regressive/transgressive depositional sequences across the outer shelf (former coastal deposits from old lowstand coast lines) and the upper slope accumulation where dating is easier, thus, resulting in an ideal area for the study of the late Quaternary sedimentary succession (Rabineau, 2001).

In this context, numerous fluid escape features, fluid pipes in the sedimentary column and related pockmarks at the seabed, provide evidence for a focused fluid flow system in the Gulf of Lion (Riboulot, 2011). The detailed observation of the pockmark geometry, obtained from High Resolution 3D seismic volume, contributed to identify the evolution through time of the fluid pipes, which are interpreted as stacked pockmarks linked to the 100-kyr cyclicity within the hosting sedimentary sequences (lowstand periods). However, the mechanism by which focused fluids move up the sedimentary column to the surface is not well constrained. During burial, the sediment porosity decreases due to loading of overlying sediments. A set of processes, such as particle re-orientation and fluid expulsion, leads to the decrease of void spaces between particles (Maltman 1994; Vasseur et al. 1995). Vertical migration of fluids through thick (up to $600 \mathrm{~m}$ ), low permeability fine-grained 


\section{A. Gay et al.}

sediments cannot occur at a rate sufficient to explain the observed seafloor seeping structures in a context known to not be actually overpressured in shallow sediments (Lafuerza et al., 2008).

\section{Cone propagation and pockmark formation}

Several authors have used physical experiments to study the formation of piercement structures in various cases: kimberlite pipes (Walters et al., 2006), hydrothermal vents (Nermoen et al., 2010), mud volcanoes (Mazzini et al., 2009), or gas seeps (Varas et al., 2009, 2011). All these experiments involved non-cohesive materials such as glass microballs and sand which were fluidized by injecting locally a fluid (air or water). They obtained similar fluidization morphologies involving a large diverging cone-like structure of remobilized material just above the fluid injection. Nermoen et al. (2010) derived analytical solutions and concluded that fluidization occurs when the seepage forces integrated over the conical fluidized area balance the weight of the granular material (Mourgues and Cobbold, 2003). Furthermore, the role of fluid pressure in the re-opening of pre-existing fractures has long been emphasized (Grauls et al., 1994 and refences therein). An increase in fluid pressure can lead to shearing (the minimum stress field is positive and the stress deviators are high) and the tensile failure (the minimum stress field is negative and the stress deviators are small). A context where the fluid pressure $(\mathrm{P})$ is almost equivalent to the minimum principal stress $\left(\sigma_{3}\right)$ will lead to the opening of fractures perpendicular to $\sigma_{3}$. So, such conditions favoring vertical fluid transfers are preferentially filled during periods of horizontal stress relaxation, once the minimum in situ stress field is less than the previously induced pressure regime $\left(\mathrm{P}>\sigma_{3}\right)$. The consequence is a reduction of the stress deviator that will initiate a negative minimum effective stress field.

The pipe identified on the North-East corner of the 3D block in the Gulf of Lion may be characterized using RMS amplitude (Fig. 8). We identified 7 well individualized intervals of low RMS amplitudes. Each interval starts with a tiny point of low RMS amplitude which evolves upward as a ring and then suddenly disappears. In a 3D view, this corresponds to vertically stacked cone structures (Fig. 9). In general, the size of the ring is wider than the depression identified on seismic sections and on the Chaos attribute.

The seismic data suggest that the most accurate interpretation for a pipe boundary is at the transition from continuous layer reflections outside and the disturbed seismic pattern inside the pipe. The pipe-fill in the pipes may therefore be structureless as observed in outcrop (Løseth et al., 2011). This would imply that layered reflections inside the pipe are geophysical artifacts. However, laterally abrupt changes in impedance values may be due to enhanced density and/or velocity contrasts, which may be related to small-scale gas accumulations associated with fluid expulsion (Taylor et al., 2000).

As previously shown in the Gjallar Ridge (Gay et al., 2012), in the North-Sea (Mourgues et al, 2011) or in the Lower Congo Basin (Monnier et al., 2013), these cone structures identified using attributes derived from 3D seismic are due to the deformation of surrounding host sediments during upward fluid propagation. The flanks of a cone appear as discrete normal faults in sandbox models due 


\section{A. Gay et al.}

to the collapse after major fluid flow (Mourgues et al., 2012; Gay et al., 2012). However, the throw is smaller than can be resolved and the faults are not clearly seen in seismic profiles with the conventional amplitude attribute. The low RMS amplitude marking the flanks may be due to the shear effect along the fault plane, locally reorienting particles and dispersing energy of the seismic signal.

The top of a cone structure does correspond to the end of pipe propagation. Sandbox models have shown that the pipe propagation induces a seafloor uplift caused by inflation of fluidcharged sediments (Gay et al., 2012). The next step in the evolution of the structure would be a collapse creating sub-circular depressions, so-called pockmarks (Mourgues et al., 2011), i.e. structures defined by a basal unconformity is seismic stratigraphy (Andresen et al., 2011). In addition, buried depressions or pockmarks mark the end of the propagation process. The levels hosting pockmarks do not correspond to the time at which fluid migration started (Gay et al., 2012).

\section{Triggering mechanisms}

Thanks to the combination of three CPTU measurements (cone resistance, lateral friction, pore pressure (Ramsey, 2002) it is possible to define the soil type based on a soil classification chart (Lafuerza et al., 2008). There is an apparent correlation between the soil type or the nature of sediments and fluid remobilization periods evidenced in the area. For example, the levels at which fluids are remobilized correspond to major lithological change, from sand or sandy-silty intervals to clayey to muddy intervals (Basseti et al., 2007).

The conventional interpretation of seismic pipes leads to the conclusion that 7 repeated events of fluid expulsion occurred for the fluid pipe located at IL211. The strong deformation of surrounding sediments is interpreted as the result of fluid pipe propagation and in some extent, the basal unconformity outlining the depression marks the end of the fluid expulsion process. More precisely, the first continuous reflection sealing the depression and the faults signs the end the upward cone propagation and related fluid pipe activity. In consequence, the base of the V-shaped structure (the cone of deformation) represents the point of fluid injection (i.e. the top of reservoir) and clearly marks the base of chimneys or pipes. The top of the V-shaped structure marks the level attained by the fluid pipe. It doesn't mean that this surface is consistent with the seafloor. Sandbox models have shown that focused migration through vertical pipes may transform into a more distributed or diffuse migration a few meters beneath the seafloor (Gay et al., 2012). This is mainly due to less cohesive sediments and higher porosity and permeability in the sub-surface. It makes difficult to identify the level (i.e. the time) at which fluid migration was initiated, although our study shows that the base of the pipes can be interpreted using a set of attributes derived from the seismic data. Seismic interpretation of amplitude-time data may lead to misinterpretation of the base of pipes and thus leads to a wrong location of fluid pressure build-ups within the sedimentary basin.

In the absence of any calibration method, it is particularly difficult to estimate the sediment thickness above the point of injection that would help in determining the head pressure $(\Delta \mathrm{h})$. 


\section{A. Gay et al.}

However, the level at which fluids started to migrate upward is located between the top of the cone structure and the base of the next overlying point of injection.

In the Gulf of Lion, core analysis in PRGL1 has shown that sediments are quite homogeneous but they are mainly composed of fine sands - silty sands - interbedded with more shaly intervals, playing the role of potential reservoirs and seal respectively. Fluids can migrate along both erosional surfaces (see Fig. 5) delineating the Herault canyon and the Bourcart canyon and they may accumulate preferentially in the sandy-silty layers forming an anticline structure at the interfluve.

However, due to the non-cohesive nature of sediments and high porosities and permeabilities in the shallow sub-surface (Lafuerza et al., 2008), the dissipation of excess porepressure is a very fast process. In order to create a focused fluid migration, an overpressure must be generated at the point of injection:

\section{1) Effect of sediment loading:}

The vertical stress due to an additional load is:

$$
\sigma_{\mathrm{v}}=\rho_{\text {sat }} \cdot \mathrm{d} \quad \text { (Equation 1) }
$$

where $\rho_{\text {sat }}$ is the bulk density (in $\mathrm{kN} . \mathrm{m}^{-3}$ ) and $\mathrm{d}$ is the thickness of the new deposit (in m). The average bulk density in the core PRGL1 is about $11,230 \mathrm{kN} \cdot \mathrm{m}^{-3}$ with a vertical stress of about $707 \mathrm{kN} . \mathrm{m}^{-2}$ (Lafuerza et al., 2008) Equation (1) gives a value of d equal or superior to about $63 \mathrm{~m}$. The thickness (d) needed to create overpressure is about $63 \mathrm{~m}$ of sediments that must be deposited almost instantly (at a geological time scale). In the area, the maximum thickness can be evaluated from event 7 , corresponding to the present day last event of fluid expulsion, and the effect of compaction is minimized. The point of initiation, or the point of injection determined on RMS amplitude time-slices (Fig. 8), is located at $434 \mathrm{~ms}$ TWT, corresponding to $9 \mathrm{~m}$ below seafloor. It means that the interval is not thick enough to generate the required overpressure for focused pipe creation. Furthermore, sedimentological core description does not evidence any catastrophic turbiditic events on the interfluve between the Herault canyon and the Bourcart canyon and the average sedimentation rate is only $1 \mathrm{~m} .10^{3} \mathrm{yr}^{-1}$ (Basseti et al., 2007; Dennielou et al., 2009).

The dissipation time of overpressured fluids ( $\mathrm{t}_{\%}$ ) depends on the hydraulic diffusivity $\mathrm{D}_{\mathrm{Z}}$ (1.10-8 $\mathrm{m}^{2} \cdot \mathrm{s}^{-1}$ in the study area, calculated from PRGL1), on the maximum vertical distance of dissipation $\mathrm{z}$ (the dissipation can be performed upward or downward, so $\mathrm{z}=9 / 2=4,5 \mathrm{~m}$ ) and on a time factor $\mathrm{T}_{\mathrm{v}}($ in $\%)$ :

$$
t \%=\frac{T v \% \cdot(z)^{2}}{D z}
$$

$\mathrm{Tv}$ is related to the consolidation rate $\mathrm{U}$ (in \%). The process of consolidation is directly linked to the rate of excess pore pressure dissipation. The one dimensional consolidation theory is governed by the following differential equation (Terzaghi, 1943):

$$
D z \frac{\partial^{2} u}{\partial z^{2}}=\frac{\partial u}{\partial t}
$$

(Equation 3) 


\section{A. Gay et al.}

where $\mathrm{u}$ is the pore water pressure, $\mathrm{Dz}$ is the hydraulic diffusivity, $\mathrm{t}$ is time and $\mathrm{z}$ denotes the position where $\mathrm{u}$ is determined. The Terzaghi's consolidation equation can be solved using analytical or numerical techniques. The solution obtained depends on the boundary conditions. For our case, with a soil layer of height, $2 \mathrm{H}$, the boundary conditions are:

(a) complete drainage at top and bottom of the layer; $\mathrm{u}=0$ at $\mathrm{z}=0$ and $\mathrm{z}=2 \mathrm{H}$;

(b) the initial excess pore water pressure $\Delta \mathrm{u}=\mathrm{u}_{\mathrm{I}}$ is equal to the applied stress increment $\Delta \sigma$.

The solution is obtained as a Fourier series, which can be expressed in the following form:
$U z=1-\sum_{n=0}^{\infty} f 1\left(\frac{z}{H}\right) f 2(T v)$
(Equation 4)

where $\mathrm{Uz}$ is the degree of consolidation at time $\mathrm{t}$, at depth $\mathrm{z}$, and $\mathrm{Tv}$ is a non-dimensional time factor. $\mathrm{Uz}$ and $\mathrm{T}$ are given by:

$$
\begin{aligned}
& T v=D z \frac{t}{H^{2} d r} \\
& U z=-\frac{u}{u i}
\end{aligned}
$$

where $H_{d r}$ is the length of the longest drainage path. Based on the numerical solution of equation (4), and in order to define the time factor $\mathrm{T}_{\mathrm{v}}$ as a function of the degree of consolidation $\mathrm{Uz}$, Casagrande (1936) and Taylor (1948) determined a 'pre-calibrated' curve concerning the Time factor Tv which is given by the following equations:

$\mathrm{Uz}>60 \%$

$$
\begin{array}{ll}
T v=1.78-0.933 \log (100-U z(\%)) & \text { (Equation 7) } \\
U z>60 \% T v=\frac{\pi}{4}\left(\frac{U z(\%)}{100}\right)^{2} & \text { (Equation 8) }
\end{array}
$$

From equations (5), (7) and (8) and for a given hydraulic diffusivity Dz and a given drainage path Hdr, it is possible to evaluate the time (t) needed to get a specified degree of consolidation Uz.

For a consolidation rate of $50 \%, \mathrm{Tv}_{50 \%}=0.197$ and Equation (2) gives a time dissipation of about 4 years. For a consolidation rate of $99 \%, \mathrm{Tv}_{99 \%}=2$, the time dissipation is about 37 years. It means that for an average sedimentation rate of $1 \mathrm{~m} \cdot 10^{3} \mathrm{yr}^{-1}, 9 \mathrm{~m}$ of sediments are deposited in 9000 years and the potential excess pore pressure is dissipated in 37 years for the best case of consolidation. So, the effect of sediment loading alone cannot be taken into account for fluid expulsion in shallow sediments of the Gulf of Lion.

\section{2) Effect of sea level variation}

In a sedimentary column, an elementary volume $\Delta \mathrm{V}$ is subjected to three forces:

(1) its own weight, Fg, due to gravity:

$$
F g=\rho s a t . \Delta V \quad \text { (Equation 9) }
$$

where Psat is the specific gravity (in $\mathrm{kN} . \mathrm{m}^{-3}$ );

(2) forces of buoyancy, $\mathrm{Fb}$, due to immersion in water:

$$
F b=\rho f . \Delta V
$$

(Equation 10) 


\section{A. Gay et al.}

where $\rho$ is the specific gravity of fluid (generally $10 \mathrm{kN} \cdot \mathrm{m}^{-3}$ );

(3) seepage forces, Fs, due to fluid flow:

$$
F s=i . \rho f . \Delta V
$$

where $\rho f$ is the specific gravity of fluid and $i$ is the hydraulic gradient, with $i=-G r a d ~ h$, where $\mathrm{h}$ represents the head pressure.

Without any specific pathways where fluid may circulate and/or accumulate, pore fluids can escape up to the seafloor if sediments are fluidized: grains become suspended in fluid, which can migrate upward. Therefore, the balance between ascending forces (Fs and Fb) and descending forces (Fg) must be equal and the hydraulic gradient, i, must reach the critical gradient, ic. For a vertical seepage, ic is given by the following equations:

$$
\rho s a t . d V=\rho f . d V+i c . \rho f . d v
$$

(Equation 12)

and

$$
\rho^{\prime}=\rho s a t-\rho f
$$

where $\rho^{\prime}$ corresponds to the submerged density. The equation (12) becomes:

$$
i c=\frac{\rho \prime}{\rho f}
$$

For fluid migration up to the seafloor, a vertical critical gradient must be taken into account from the point of initiation to the seafloor:

$$
i=\frac{\Delta H}{L}=i c=\frac{\rho \prime}{\rho f}
$$

where $\Delta \mathrm{H}$ is the variation of head pressures between the point of initiation and the seafloor and $\mathrm{L}$ represents the thickness between these two points.

For an average specific gravity, $\rho$ sat, of $3,9 \mathrm{kN} \cdot \mathrm{m}^{-3}$ in the first $100 \mathrm{~m}$ of the sedimentary column calculated from PRGL1 site (Lafuerza et al. 2008), a specific gravity of seawater, $\rho$, of 1,03 $\mathrm{kN} . \mathrm{m}^{-3}$, and $9 \mathrm{~m}$ for L corresponding to the burial depth of the event 7 initiation point $(9 \mathrm{~m}$ below seafloor), the variation of head pressure is $34,2 \mathrm{~m}$, representing an excess pore pressure of $334 \mathrm{kPa}$ (considering g equal to $9,81 \mathrm{~m} \cdot \mathrm{s}^{-1}$ ).

An excess pore pressure of $334 \mathrm{kPa}$ can be created by a sea level rise, increasing pore water pressure at depth only in drained conditions. The needed sea level rise (H1-H0) for such an excess pore pressure able to create fluidization and expulsion can be calculated:

$$
\Delta P=(H 1-H 0) \cdot g r a d P s \quad \text { (Equation } 16)
$$

Where $\Delta \mathrm{P}$ represents an excess pore pressure of $334 \mathrm{kPa}$ at $9 \mathrm{~m}$ below seafloor, $\mathrm{H} 1$ is the actual bathymetry of $300 \mathrm{~m}, \mathrm{H} 0$ is the initial bathymetry, and gradPs is about $10,07 \mathrm{kPa}^{-1}$ in seawater. The calculated bathymetry, H0, is about $266 \mathrm{~m}$, giving a sea level rise of about $+34 \mathrm{~m}$.

The measurement of Relative Sea Level (RSL) can be done relative to present day Sea Level $(\mathrm{t}=0)$. Paleobathymetry is usually estimated from cores with a description and evolution of sedimentary facies with microfossil assemblages (Ferland et al., 1995; Yokoyama et al., 2000; Hanebuth et al., 2000) and must be corrected from the subsidence effect. The most accurate study has 


\section{A. Gay et al.}

directly estimated the RSL in the western part of the Gulf of Lion from seismic data (Rabineau et al., 2006). They provided the position of the delta front at the last glacial maximum MIS2 giving an estimated value of $102 \pm 6 \mathrm{~m}$ at MIS 2.2 stage. This value is consistent with previous estimates in the region based on molluscs ages (Aloïsi et al., 1975; Labeyrie et al., 1976; Aloïsi et al., 1993) and also based on glacio-hydro isostatic modeling. More recent studies suggested a RSL of at least $-115 \mathrm{~m}$ but this value is not corrected from subsidence of the shelf (Jouet et al., 2006).

A sea level rise of about $+34 \mathrm{~m}$ triggering fluid expulsion during event 7 is consistent with a global sea level rise of about 102 to $115 \mathrm{~m}$ since the last glacial maximum MIS 2.2 stage. A quick look at all other pipes present in 3D seismic area shows that the last event of fluid expulsion (event 7) is marked by cones of deformation accompanying the upward fluid pipe propagation. As the initiation point is situated at the same stratigraphic level, it means that most of the modern pockmarks were generated during the last sea level rise. Further investigations are required in order to check out whether the Gulf of Lion experienced a major fluid release since the last glacial stage as shown in other basins (Plaza-Faverola et al., 2011). For instance, in the Ceuta Drift and the Gulf of Cadiz, high resolution images have revealed that the pockmarks are connected to shallow subsurface reservoirs (Leon et al., 2010; Leon et al., 2014). In such environment, coarser-grained sediments can act as reservoirs for fluid accumulation and overlying fine-grained sediments may act as effective seals (Somoza et al., 2012; Leon et al., 2014). In this area, pockmarks are associated with the first subsurface erosion surface which is overlain by a transparent layer representing the final transgressive Holocene deposit (Leon et al., 2014). The decrease in hydrostatic pressure during the sea-level lowstand resulted in the expansion of sediment-trapped bubbles within the shallow subsurface reservoirs. At the same time, rhythmic tidal water level changes and large internal waves acted as "hydraulic pumps" of the shallow subsurface free gas accumulations (Leon et al., 2014). At the beginning of the transgressive period, seawater coming from the Atlantic Ocean started to overflow into the Mediterranean Sea creating internal waves (Leon et al., 2014). This event can be recorded at shallower depths $(<100 \mathrm{~m})$ where the internal waves interacted with the sea bottom to form giant sand waves, like in the Gulf of Valencia (Albarracin et al., 2014). The propagation of internal waves alongshore may act together with the general sea-level rise at the beginning of the transgressive period as a hydraulic pump for fluids trapped at shallow depths, resulting in the formation of pockmarks (Leon et al., 2014). It means that, for each start of transgression, large amount of methane-rich fluids were possibly released into the ocean and atmosphere, possibly increasing the greenhouse effect (Dunkley Jones et al., 2010).

\section{A model for cyclic fluid expulsions}

A recent geotechnical survey, conducted northwest and southeast of the study area (Sultan et al., 2007) has shown only one active gas emission within a pockmark. Based on in situ pore pressure measurements, they considered that the excess pore pressures and pockmark activities observed were most likely associated with the presence of free gas that partially saturated underlying 


\section{A. Gay et al.}

sedimentary layers. Furthermore, deep sea benthic analyses have shown that sediments within the active pockmark fields had lower meiofaunal abundance and biomass when compared with the surrounding sediments that were not influenced by the gas seepage (Zeppilli et al., 2012). All other investigated pockmarks in the area are inactive at the present day (Sultan et al., 2007; Zeppilli et al., 2012). This clearly indicates that 1) fluids are actively migrating from deeper levels. Given the geological context of the interfluve, they are possibly driven through erosional surfaces or discontinuities; 2) fluids are accumulating in silt to sand-rich shallow buried levels leading to an actual increase in pore pressure; and 3) fluids are trapped under a low-permeability seal; and 4) fluids can escape at the seafloor in only a few places, the fluid escape is in a quiescence mode. This period is illustrated on Fig. 10 as stages A or E where there is a pressure build-up within a shallow buried siltrich layer overlain by a mud-rich interval.

The pressure build-up is generated due to the fluid accumulation, leading to the development of a cone of deformation in overlying sediments and a bulge (or doming) at the seafloor (stage B, Fig. 10), as shown in other basins (Mourgues et al., 2012).

The possibility of dilatancy can be considered here due to erosion of the structure at the seafloor. The fluid pipe can vertically propagate along pre-formed cracks at stage B. Most of the fluids are released at this stage, leading to a collapse of the structure creating the seafloor depression (Gay et al., 2012; Dumke et al., 2014), or pockmark (stage C, Fig. 10). During stage B, the anticline structure developing between both turbiditic canyons is in a compressive regime bringing about a significant increase in fluid pressure although relaxation period alone will allow fluid to migrate upward at stage C. Then, during sea level highstand or continuing sea-level rise, the seafloor structures are smoothly drapped by clayey hemipelagic sediments interlayered with thin beds of sand or silty sands (Basseti et al., 2007) (Stage D, Fig. 10). This stage of drapping is then accompanied or followed by a new period of fluid accumulation in more porous silty-sandy to sandy intervals, It can be called the recharge period (Stage E, Fig. 10). The next step is a new period of release unless the amplitude of sea level, or the depth of the reservoir, does not allow an excess pore pressure sufficient for triggering fluid expulsion.

\section{Conclusion}

3D seismic data provide new insights on the Gulf of Lion fluid migration history. It substantially improves the understanding of post-depositional processes that affect the sedimentary column in shallow subsurface. Analysis of such data makes it possible to understand the link between fluid pipes propagation and associated V-shaped structures. As previously shown in other basins, these cone structures may develop in response to the deformation of surrounding sediments during fluid migration in the near surface. They cannot be evidenced in a traditional way using seismic amplitude only and a set of derived attributes, such as RMS amplitude coupled to Chaos, must be calculated. 


\section{A. Gay et al.}

They allow the precise 3D mapping of the point of fluid injections in overlying sediments and the top of the cone structure marks the top of the focused migration. Based on these observations we focused on one example of fluid pipe characterized by repeated cycles of fluid expulsion. We have shown that these expulsion events might be correlated with sea level rise instead of sediment loading. The most recent event (event 7 corresponding to MIS 2.2 stage) has led to the formation of a pockmark on the modern seafloor. It has been used as a reference for calculating the effect of sea level rise on fluid expulsion. As all physical and geometrical parameters are constrained, we were able to define that a $+34 \mathrm{~m}$ of sea level rise may account for triggering fluid expulsion since the last glacial stage. This value is consistent with a sea level rise of about $102 \mathrm{~m}$ during this period.

We propose a model that integrates with previous hypotheses. However, interpreting seismic facies alone doesn't provide the key for having the full picture of fluid migration processes in the shallow sub-surface. The assumption that the sea level rise, or the speed at which sea level is rising up, may be responsible for triggering fluid escape is highly relevant for predictive models describing the occurrence of pockmarks on slopes (implications for human activities such as cable, pipelines or platform anchors) and may account for large greenhouse gas release into the ocean and atmosphere (implication for climate change). The processes of fractures opening and fluid build-up in shallow reservoirs of lower pressure regimes preferentially occur during the relaxation phases of lateral tectonic stresses and as soon as the effective minimum stress become negative. Such conditions can be reached during sea-level rise in the Gulf of Lion.

\section{Acknowledgements}

We gratefully acknowledge the SHOM which co-acquired with IFREMER the HR 3D seismic data for this study. This project was supported by the Action-Marges funding, part of the French INSU program. We would like to thank miss Audrey Laplanche who was a master student involved in this project.

\section{List of Figures}

Figure 1: Location map of the study area in the Gulf of Lion, NW Mediterranean Sea. The 3D seismic dataset (white rectangle) is oriented NE-SW.

Figure 2: Shaded bathymetric map showing the Bourcart and Hérault canyons between 200 and 800 $m$ water depth (modified after Berné et al., 2004). The 3D seismic dataset is located on the interfluves between the canyons. The well PRGL 1 is located within the 3D seismic dataset allowing correlations.

Figure 3: Correlation between CPTU-based geotechnical stratigraphy and seismic reflection stratigraphy at PRGL1site (modified from Lafuerza et al., 2008).

Figure 4: 3D shaded relief map extracted from the 3D seismic dataset. About 180 pockmarks have been identified on the seafloor. They are mostly concentrated on the top of the anticline structure corresponding to the interfluves between the Bourcart and the Hérault canyons. 


\section{A. Gay et al.}

Figure 5: Seismic profile IL 211 crossing the study area from NE to SW. This profile shows one of the most prominent seismic anomaly beneath a seafloor pockmark located on the top of the interfluves between the Bourcart and the Hérault canyons. Slopes on both sides of the interfluves are characterized by erosional surfaces, onlap or drapping structures and high amplitude anomalies.

Figure 6: Zoomed in cross sections from IL 207 to IL 239 oriented NE-SW (See Fig. 4 and 5 for location). This set of seismic profiles displays the 3D geometry of the anomaly beneath the pockmark.

Figure 7: Time slices of amplitude of Chaos from $400 \mathrm{~ms}$ TWT to $750 \mathrm{~ms}$ TWT (See Fig. 4 for location). The pipes are represented by spots of high amplitude of chaos surrounded by rings of medium amplitude of chaos.

Figure 8: RMS profile of IL 211 showing the vertical succession of anomalies from D45 stratigraphic level to the seafloor (See Fig. 4, 5 and 7 for location). 7 intervals have been identified on RMS time slices, starting at the base with a spot (the point of initiation) slightly evolving upward to a ring. This structure defines a cone in 3D, or a V-shaped anomaly on 2D sections. They are associated with cones of deformation that develop during a fluid pipe propagation (Mourgues et al., 2011, 2012; Gay et al., 2012). The top of a cone marks the time at which the propagation started.

Figure 9: Correlation between the 7 cycles of pipe propagation and associated cone of deformation and the sea level variation deduced from de $\delta^{18} \mathrm{O}$ curve. These expulsion events might be correlated with sea level rise instead of sediment loading. The most recent event (event 7 corresponding to MIS 2.2 stage) has led to the formation of a seafloor pockmark.

Figure 10: Conceptual model for the development of a cyclic fluid expulsion: A) initiation during a sea level rise, B) pipe propagation and associated cone of deformation, C) Seafloor collapse and major fluid expulsion, D) end of expulsion and drapping, E) accumulation stage.

\section{References}

Abrams, M.A. 1992. Geophysical and geochemical evidence for subsurface hydrocarbon leakage in the Bering Sea, Alaska. Marine and Petroleum Geology Bulletin, 9, 208-221.

Albarracín, S., Alcántara-Carrió J., Montoya-Montes I., Fontán-Bouzas, A., Somoza, L. Amos, C.A., Rey, J. Relict wand waves in the continental shelf of the Gulf of Valencia (Western Mediterranean). Journal of Sea Research 93, 33-46.Aloïsi, J.C., Monaco, A., Thommeret, J. and Thommeret, Y., 1975. Evolution paléogéographique du plateau continental languedocien dans le cadre du golfe du Lion; Analyse comparée des données sismiques, sédimentologiques et radiométriques concernant le Quaternaire récent. Rev. Géogr. Phys. Géol. Dyn., 17(1): 13-22.

Aloïsi, J.C., 1993. Sea Level Variations on the French Mediterranean Margin during the Holocene. Paleoclimate Research; Paläklimaforshung ${ }^{\circ}{ }^{\circ}$ spec: 25.

Anderson, A. and Hampton, L.D., 1980. Acoustics of gas-bearing sediments .2. Measurements and models. Journal of Acoustical Society of America, 67: 1890-1903.

Andresen, K.J. and Huuse, M., 2011. "Bulls-eye" pockmarks and polygonal faulting in the Lower Congo Basin: relative timing and implications for fluid expulsion during shallow burial. Marine Geology, 279(1-4): 111-127. 
Arntsen, B., Wensaas, L., Løseth, H. and Hermanrud, C., 2007. Seismic modelling of gas chimneys. Geophysics, 72: 251-259.

Baraza, J. and Ercilla, G., 1996. Gas-charged sediments and large pockmark-like features on the Gulf of Cadiz slope (SW Spain). Marine and Petroleum Geology, 13(2): 253-261.

Baztan, J., Berné, S., et al., 2005. 2005. Axial incision: The key to understand submarine canyon evolution (in the western Gulf of Lion). Marine and Petroleum Geology, 22(6-7): 805-826.

Bassetti, M.A. et al., 2008. The 100-ka and rapid sea level changes recorded by prograding shelf sand bodies in the Gulf of Lions (western Mediterranean Sea). Geochemistry Geophysics Geosystems, 9(11): doi:10.1029/2007GC001854.

Berndt, C. 2005. Focused fluid flow on continental margins. Philosophical Transactions of the Royal Society Series A, 363, 2855-2871.

Berné, S., Carré, D., Loubrieu, B., Mazé, J.-P. and Normand, A., 2001. Carte morphobathymétrique du Golfe du Lion à l' échelle 1/100 000ème. IFREMER et Région Languedoc Roussillon, Brest.

Berné, S., M. Rabineau, J.A. Flores, and F.J. Sierro. 2004. The impact of quaternary global changes on strata formation: Exploration of the shelf edge in the northwest Mediterranean Sea. Oceanography 17(4):92-103, http://dx.doi.org/10.5670/oceanog.2004.07.

Boe, R., Rise, L. and Ottesen, D., 1998. Elongate depressions on the southern slope of the Nowegian trench(Skagerrak) : morphology and evolution. Marine Geology, 146: 191-203.

Brown, A. 2000. Evaluation of possible gas microseepage mechanisms. AAPG Bulletin, 84, 17751789.

Canals, M. et al., 2006. Flushing submarine canyons. Nature, 444: 354-357.

Cartwright, J., Huuse, M. and Aplin, A.C., 2007. Seal bypass system. AAPG bulletin, 91(8): 1141 1166.

Casagrande, A., 1936. Characteristics of cohesionless soils affecting the stability of slopes and earth fills. Journal of Boston Soc. Civil Engrs., Vol. 23: p. 13-32.

Cifci, G., Dondurur, D. and Ergun, M., 2003. Deep and shallow structures of large pockmarks in the Turkish shelf, Eastern Black Sea. Geo-Marine Letters, 23: 311-322.

Cochonat, P. et al., 2002. Slope instabilities and gravity processes in fluid migration and tectonically active environment in the eastern Nankai accretionary wedge (KAIKO-Tokai'96 cruise). Marine Geology, 187: 193-202.

Dennielou, B. et al., 2009. Post-glacial persistence of turbiditic activity within the Rhone deep-sea turbidite system (Gulf of Lions, Western Mediterranean): Linking the outer shelf and the basin sedimentary records Marine Geology, 257(1-4): 65-86.

Dimitrov, L. and Woodside, J., 2003. Deep sea pockmarks environments in the eastern Mediterranean. Marine Geology, 195: 263-276.

Dumke, I., Berndt, C., Crutchley, G.J., Krause, S., Liebetrau, V., Gay, A., Couillard, M., 2014. Seal bypass at the Giant Gjallar Vent (Norwegian Sea): Indications for a new phase of fluid venting at a 56-Ma-old fluid migration system. Marine Geology, 351: 38-52.

Dunkley Jones, T. et al., 2010. A Palaeogene perspective on climate sensitivity and methane hydrate instability. Philosophical Transactions of the Royal Society a-Mathematical Physical and Engineering Sciences, 368(1919): 2395-2415.

Eichhubl, P., Greene, H.G., Naehr, T. and Maher, N., 2000. Structural control of fluid flow: offshore fluid seepage in the Santa Barbara Basin, California. Journal of Geochemical Exploration, 69/70: 545-549.

Elverhoi, A., De Blasio, F.V., Butt, F.A., Issler, D., Harbitz, C.B., Engvik, L., Solheim, A. \& Marr, J., 2002. Submarine mass-wasting on glacially influenced continental slopes - processes and dynamics. In: Dowdeswell, J.A. \& O'Cofaigh, C. (eds), Glacier-influenced Sedimentation on high Latitude Continental Margins. Geological Society, London, Special Publication, 203, 7387. 


\section{A. Gay et al.}

Evans, D., King, E.L., Kenyon, N.H., Brett, C. \& Wallis, D. 1996. Evidence for long-term instability in the Storegga Slide region off western Norway. Marine Geology, 130, 281-292.

Ferland, M., Roy, P. and Murray-Wallace, C., 1995. Glacial lowstand deposits on the outer continental shelf of Southeastern Australia. Quaternary Research, 44: 294-299.

Frigola, J. et al., 2012. A $500 \mathrm{kyr}$ record of global sea-level oscillations in the Gulf of Lion, Mediterranean Sea: new insights into MIS 3 sea-level variability. Climate Past, 8: 1067-1077.

Gaudin, M. et al., 2006. Massive sand beds attributed to deposition by dense water cascades in the Bourcart canyon head, Gulf of Lions (northwestern Mediterranean Sea). Marine Geology, 234: 111-128.

Gay, A. et al., 2003. Sinuous pockmark belt as indicator of a shallow buried turbiditic channel on the lower slope of the Congo Basin, West African Margin. In: P. Van Rensbergen, R.R. Hillis, A.J. Maltman and C.K. Morley (Editors), Subsurface Sediment Mobilization. Special Publications. Geological Society of London, pp. 173-189.

Gay, A. et al., 2006. Seafloor facies related to upward methane flux within a Giant Pockmark of the Lower Congo Basin. Marine Geology, 226(1-2): 81-95.

Gay, A. et al., 2006. Isolated seafloor pockmarks linked to BSRs, fluid chimneys, polygonal faults and stacked Oligocene-Miocene turbiditic palaeochannels in the Lower Congo Basin. Marine Geology, 226: 25-40.

Gay, A. et al., 2006. Evidences of early to late fluid migration from an upper Miocene turbiditic channel revealed by 3D seismic coupled to geochemical sampling within seafloor pockmarks, Lower Congo Basin. Marine and Petroleum Geology, 23: 387-399.

Gay, A., Lopez, M., Berndt, C. and Séranne, M., 2007a. Geological controls on focused fluid flow associated with seafloor seeps in the Lower Congo Basin. Marine Geology, 244: 68-92.

Gay, A. \& C. Berndt, 2007b. Cessation/reactivation of polygonal faulting and effect on fluid flow in the Voring Basin, Norwegian Margin. Journal of the Geological Society of London. Vol. 164, 129-141.

Gay, A. et al., 2012. Anatomy of a fluid pipe in the Norway Basin: Initiation, propagation and 3D shape. Marine Geology, 332: 75-88.

Grauls, D. and Baleix, J.M., 1994. Role of overpressures and in situ stresses in fault controlled hydrocarbon migration: a case study. Marine and Petroleum Geology, 11(6): 734-742.

Gutowski, M. et al., 2008. Three-dimensional high-resolution acoustic imaging of the sub-seabed. Applied Acoustics, 69: 412-421.

Hanebuth, T., Stattegger, K. and Grootes, P.M., 2000. Rapid flooding of the Sunda Shelf: a LateGlacial sea-level record. Science, 288: 1033-1035.

Heggland, R., 1997. Detection of gas migration from a deep source by the use of exploration 3D seismic data. Marine Geology, 13: 41-47.

Hempel, P., Spiess, V. \& Schreiber, R. 1994. Expulsion of shallow gas in the Skagerrak- Evidence from subbottom profiling, seismic, hydroacoustical and geochemical data. Estuarine, Coastal and Shelf Science, 38, 583-601.

Hovland, M., 1981. Characteristics of pockmarks in the Norwegian trench. Marine Geology, 39: 103117.

Hovland, M. and Judd, J., 1988. Seabed pockmarks and seepages. Impact on Geology, Biology and Marine Environment. Graham and Trotman, London, 293 pp.

Josenhans, H.W., King, L.H. and Fader, G.B., 1978. A side-scan sonar mosaic of pockmarks on the Scotian shelf. Canadian Journal of Earth Sciences, 15: 831-840.

Jouet, G. et al., 2006. Shoreface migrations at the shelf edge and sea-level changes around the Last Glacial Maximum (Gulf of Lions, NW Mediterranean). Marine Geology, 234: 21-42.

Jouet, G. 2007. Enregistrements stratigraphiques des cycles climatiques et glacio-eustatiques du Quaternaire terminal-Modélisations de la marge continentale du Golfe du Lion, PhD Thesis, 


\section{A. Gay et al.}

Laboratoire Environnements Sédimentaires, Géosciences Marines. Ifremer, Brest, France, 443 pp.

Judd, A.G., Hovland, M., Dimitrov, L.I., Garcia Gil, S. and Jukes, V., 2002. The geological methane budget at continental margins and its influence on climate change. Geofluids, 2: 109-126.Judd, A.G. and Hovland, M., 1992. The evidence of shallow gas in marine sediments. Continental Shelf Research, Vol. 12(No. 10): p. 1081-1095.

Judd, A., Long, D. and Sankey, M., 1992. Pockmark formation and activity, UK block 15/25, North Sea. Bulletin of the Geological Society of Denmark, 41: 34-49.

Kelley, J.T., Dickson, S.M., Belknap, D.F., Barnhardt, W.A. and Henderson, M., 1994. Giant sea-bed pockmarks: evidence for gas escape from Belfast Bay, Maine. Geology, 22: 59-62.

King, L.H. and MacLean, B., 1970. Pockmarks on the Scotian shelf. Geological Society of America Bulletin, Vol. 81: p. 3141-3148.

Labeyrie, J., Lalou, C., Monaco, A. and Thommeret, J., 1976. Chronologie des niveaux eustatiques sur la côte du Roussillon de-33000 ans B.P. à nos jours. Comptes Rendus de l'AcadÃ@mie des Sciences de Paris, 282: 349-352.

Lafuerza, S. et al., 2008. Subseafloor stratigraphic profiling and soil classification from piezocone tests: A case study in the Gulf of Lion (NW Mediterranean Sea). Geochemistry Geophysics Geosystems, 9(12): Q12028.

León, R., Somoza, L., Medialdea, T., Gonzalez, FJ, Gimenez-Moreno, CJ, Perez-Lopez, R. (2014). Pockmarks on either side of the Strait of Gibraltar: formation from overpressured shallow contourite gas reservoirs and internal wave action during the last glacial sea-level lowstand? Geo-Marine Letters Volume: 34 2-3: 131-151.

León R, Somoza L, Medialdea T, Hernández-Molina FJ, Vázquez JT, Díaz-del-Rio V, González FJ (2010) Pockmarks, collapses and blind valleys in the Gulf of Cádiz. Geo-Marine Letters 30(3/4):231-247.

Ligtenberg, H., 2005. Detection of fluid migration pathways in seismic data: implications for fault seal analysis. Basin Research, 17: 141-153.

Løseth, H. et al., 2011. 1000 m long gas blow-out pipes. Marine and Petroleum Geology, 28: 10471060 .

Maltman, A., 1994. The Geological Deformation of Sediments, Chapman \& Hall, London, 362 p.

Marsset B., Thomas, Y., Sultan, N., Gaillot, A., Stephan, Y. (2012). A multi-disciplinary approach to marine shallow geohazard assessment. Near Surface Geophysics, 10(4), 279-288. http://dx.doi.org/10.3997/1873-0604.2012012

Mazzini, A. et al., 2009. Strike-slip faulting as a trigger mechanism for overpressure release through piercement structures. Implications for the Lusi mud volcano, Indonesia. Marine and Petroleum Geology, 26(9): 1751-1765.

Monnier, D., Imbert, P., Gay, A., Lopez, M. and Mourgues, R., (2012). Pliocene sand injectites from a submarine lobe fringe during hydrocarbon migration (and sal diapirism): a seismic example from the Lower Congo Basin. Geofluids.

Mourgues, R. and Cobbold, P.R., 2003. Some tectonic consequences of fluid overpressures and seepage forces as demonstrated by sandbox modelling. Tectonophysics, 376: 75-97.

Mourgues, R., Bureau, D., Bodet, L., Gay, A. and Gressier, J., 2012. Formation of conical fractures in sedimentary basins: Experiments involving pore fluids and implications for sandstone intrusion mechanisms. Earth and Planetary Science Letters, 313: 67-78.

Mourgues, R., Gressier, J.B., Bodet, L., Bureau, D. and Gay, A., 2011. "Basin scale" versus "localized" pore pressure/stress coupling e Implications for trap integrity evaluation. Marine and Petroleum Geology, 28(5): 1111-1121.

Nakajima, T. et al., in press. Formation of pockmarks and submarine canyons associated with dissociation of gas hydrates on the Joetsu Knoll, eastern margin of the Sea of Japan. Journal of Asian Earth Sciences. 


\section{A. Gay et al.}

Nermoen, A. et al., 2010. Experimental and analytic modeling of piercement structures. Journal of Geophysical Research-Solid Earth, 115(B10202).

Orange, D.L., Greene, H.G., Reed, D., Martin, J.B., McHugh, C.M., Ryan, W.B.F., Maher, N., Stakes, D. \& Barry, J. 1999. Widespread fluid expulsion on a translational continental margin: Mud volcanoes, fault zones, headless canyons, and organic-rich substrate in Monterey Bay, California. Geological Society of America Bulletin, 111, 992-1009.

Palanques, A. et al., 2006. Suspended sediment fluxes and transport processes in the Gulf of Lions submarine canyons. The role of storms and dense water cascading. Marine Geology, 234: 4361.

Pasqual, C. et al., 2010. Flux and composition of settling particles across the continental margin of the Gulf of Lion: the role of dense shelf water cascading. Biogeosciences, 7: 217-231.

Plaza-Faverola, A., Bunz, S. and Mienert, J., 2011. Repeated fluid expulsion through sub-seabed chimneys offshore Norway in response to glacial cycles. Earth and Planetary Science Letters, 305(3-4): 297-308.

Pont, D., Simonnet, J.P. and Walter, A.V., 2002. Medium-term Changes in Suspended Sediment Delivery to the Ocean: Consequences of Catchment Heterogeneity and River Management (Rhone River, France). Estuarine, Coastal and Shelf Science, 54: 1-18.

Posamentier, H.W., Allen, G.P., James, D.P. and Tesson, M., 1992. Forced regressions in a sequence stratigraphic framework: concepts, examples, and exploration significance. AAPG bulletin, 76: 1687-1709.

Prior, D.B. and Coleman, J.B., 1984. Submarine slope instability. In: D. Brunsden and D.B. Prior (Editors), Slope Instability. Wiley, New York, pp. 419-455.

Rabineau, M., 2001. Un modèle géométrique et stratigraphique des séquences de dépôts quaternaires de la plate-forme du Golfe du Lion: enregistrement des cycles glacioeustatiques de 100000 ans., Université de Rennes, Rennes, 392 pp.

Rabineau, M. et al., 2006. Paleo sea levels reconsidered from direct observation of paleoshoreline position during Glacial Maxima (for the last 500,000 yr). Earth and Planetary Science Letters, 252: 119-137.

Ramsey, N., 2002. A calibrated model for the interpretation of cone penetration tests (CPTs) in North Sea quaternary soils. In: M.e.a. Cook (Editor), Offshore Site Investigation and Geotechnics: Diversity and Sustainability. Society for Underwater Technology, London, pp. 341-356.

Riboulot, V., 2011. Facteurs de contrôle du fonctionnement des pockmarks durant les derniers cycles climatiques (Partie orientale du delta sous-marin du Niger et Golfe du Lion), Université de Perpignan Via Domitia, Perpignan, France, 243 pp.

Rodrigues, N., Cobbold, P.R. and Løseth, H., 2009. Physical modelling of sand injectites. Tectonophysics, 474: 610-632.

Rollet, N. et al., 2006. Characterisation and correlation of active hydrocarbon seepage using geophysical data sets: An example from the tropical, carbonate Yampi Shelf, Northwest Australia. Marine and Petroleum Geology, 23(2): 145-164.

Sanchez-Vidal, A. et al., 2008. Impact of dense shelf water cascading on the transfer of organic matter to the deep western Mediterranean basin. Geophysical Research Letters, 35: L05605.

Satyavani, N., Thakur, N.K., Aravind Kumar, N. and Reddi, S.I., 2005. Migration of methane at the diapiric structure of the western continental margin of India. Marine Geology, 219: 19-25.

Schroot, B.M., Klaver, G.T. and Schüttenhelm, R.T.E., 2005. Surface and subsurface expressions of gas seepage to the seabed - examples from the Southern North Sea. Marine and Petroleum Geology, 22: 499-515.

Shaw, J., Courtney, R.C. and Currie, J.R., 1997. Marine geology of St. George's Bay, Newfoundland, as interpreted from multibeam bathymetry and back-scatter data. Geo-Marine Letters, 17: 188194. 


\section{A. Gay et al.}

Sibuet, M., 2003. Cold seep communities on continental margins; structure and quantitative distribution relative to geological and fluid venting patterns. In: G. Wefer et al. (Editors), Ocean margin systems. Springer-Verlag, Bremen, pp. 235-251.

Solheim, A. and Elverhoi, A., 1993. Gas-related sea floor craters in the Barents Sea. Geo-Marine Letters, 13: 235-243.

Somoza, L., Medialdea T., R. León, G. Ercilla, J. T. Vázquez, M. Farran, J. Hernández-Molina, J. González, C. Juan, M. C. Fernández-Puga. (2012) Structure of mud volcano systems and pockmarks in the region of the Ceuta Contourite Depositional System (Western Alborán Sea). Marine Geology 332-334: 4-26

Soter, S., 1999. Macroscopic seismic anomalies and submarine pockmarks in the Corinth-Patras rift, Greece. Tectonophysics, 308: 275-290.

Sultan, N., Cochonat, P., Bourillet, J.-F. and Cayocca, F., 2001. Evaluation of the risk of marine slope instability: a pseudo-3D approach for application to large areas. Marine Georesources and Geotechnology, 19: 107-133.

Sultan, N., Gaudin, M., Berne, S., Canals, M., Urgeles, R. \& Lafuerza, S. (2007) Analysis of slope

failures in submarine canyon heads: an example from the Gulf of Lions. Journal of Geophysical

Research, 112, F01009.

Taylor, D.W., 1948. Fundamentals of soil mechanics. John Wiley, New York.

Taylor, M.H., Dillon, W.P. and Pecher, I.A., 2000. Trapping and migration of methane associated with the gas hydrate stability zone at the Blake Ridge Diapir: new insights from seismic data. Marine Geology, 164: 79-89.

Terzaghi, K., 1943. Theoretical soil mechanics. John Wiley, New York.

Tesson, M., Gensous, B., Allen, G.P. and Ravenne, C., 1990. Late Quaternary deltaic lowstand wedges on the Rhône continental shelf, France. Marine Geology, 91: 325-332.

Tesson, M., Posamentier, H.W. and Gensous, B., 2000. Stratigraphic organization of late pleistocene deposits of the western part of the Golfe du Lion shelf (Languedoc shelf), Western Mediterranean Sea, using high-resolution seismic and core data. AAPG bulletin, 84: 119-150.

Thomas Y., Marsset B., Didailler S., Regnault J.P., Le Conte S., Le Roux D., Farcy P., Magueur M., Viollette P., Herveou J., Guedes J.C., Jegot B., Gascon G., Prud'homme C., Nouzé H., Thereau E., Contrucci I. and Foucher J.P. 2004. High Resolution marine 3D seismic: A new surveying tool for the Scientific Community. Comptes Rendus Géoscience 336, 579-585.

Thomas, Y. et al., 2012. Contribution of high-resolution 3D seismic near-seafloor imaging to reservoir-scale studies: application to the active North Anatolian Fault, Sea of Marmara. Near Surface Geophysics, 10: 291-301.

Tingdahl, K.M., Bril, A.H. \& de Groot, P.F. 2001. Improving seismic chimney detection using directional attributes. Journal of Petroleum Science and Engineering, 29, 205-211.

Varas, G., Vidal, V. and Geminard, J.J., 2009. Dynamics of crater formations in immersed granular materials. Physical Review E, 79(2): 021301(7).

Varas, G., Vidal, V. and Geminard, J.J., 2011. Venting dynamics of an immersed granular layer. Physical Review E, 83(1): 011302(6).

Vasseur, G., Djeran-Maigre, I., Grunberger, D., Rousset, G., Tessier, D. \& Velde, B. 1995. Evolution of structural and physical parameters of clays during experimental compaction. Marine and Petroleum Geology, 12, 941-954.

Vogt, P.R., Gardner, J. and Krane, K., 1999. The Norwegian-Barents-Svalbard (NBS) continental margin: Introducing a natural laboratory of mass wasting, hydrates, and ascent of sediment, pore water, and methane. Geo-Marine Letters, 19: 2-21.

Walters, A.L. et al., 2006. The role of fluidisation in the formation of volcaniclastic kimberlite: Grain size observations and experimental investigation. J. Volcanol. Geotherm. Res., 155: 119-137.

Werner, F., 1978. Depressions in mud sediments (Eckernfoerde Bay, Baltic Sea) related to sub-bottom and currents. Meyniana, 30: 99-104. 


\section{A. Gay et al.}

894

895

896

897

898

899

900

901

902

903

904

905

906

907

908

909

Whiticar, M.J. and Werner, F., 1981. Pockmarks : Submarine vents of natural gas or freshwater seeps ? Geo-Marine Letters, 1: 193-199.

Yokoyama, Y., Lambeck, K., Johnston, P. and Fifield, L.K., 2000. Timing of the Last Glacial Maximum from observed sea-level minima. Nature, 406: 713-716.

Yun, J.W., Orange, D.L. and Field, M.E., 1999. Subsurface gas offshore of northern California and its link to submarine geomorphology. Marine Geology, Vol. 154: p. 357-368.

Zeppilli, D., Canals, M., Danovaro, R. 2012. Pockmarks enhance deep-sea benthic biodiversity: a case study in the western Mediterranean Sea. Diversity \& Distributions, Vol. 18: Issue 8, p. 832-846.

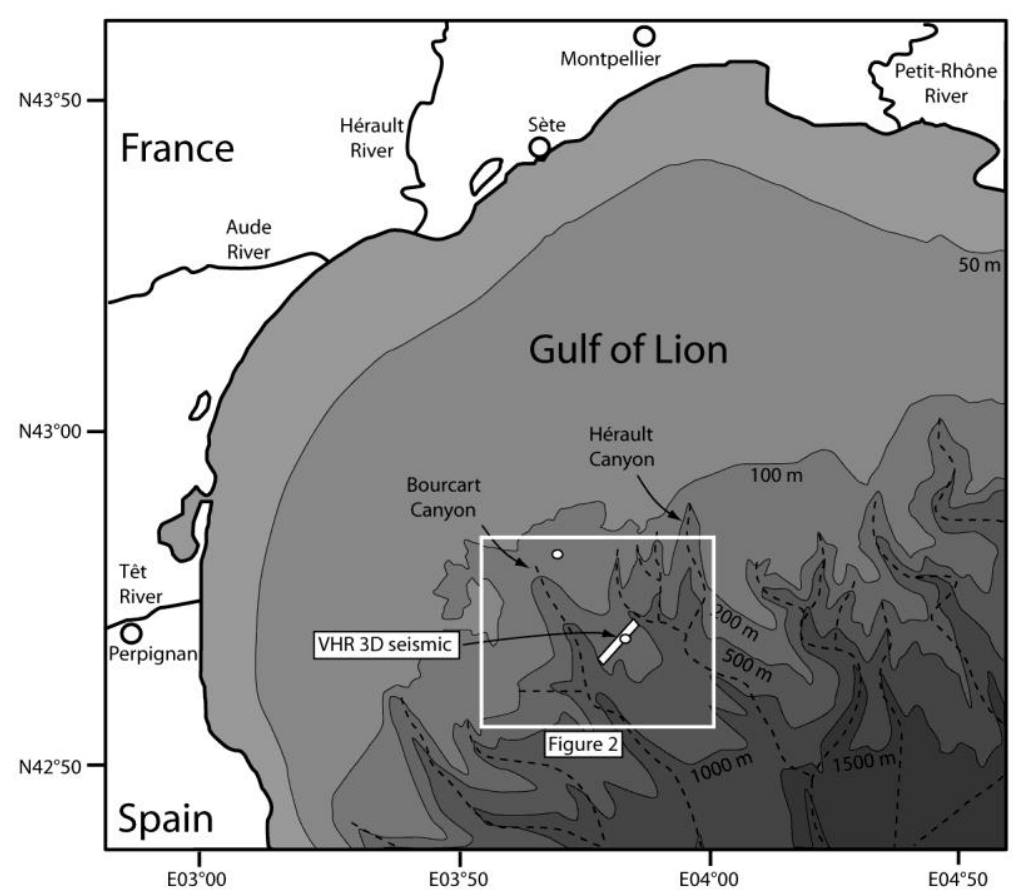

Fig. 1 


\section{A. Gay et al.}

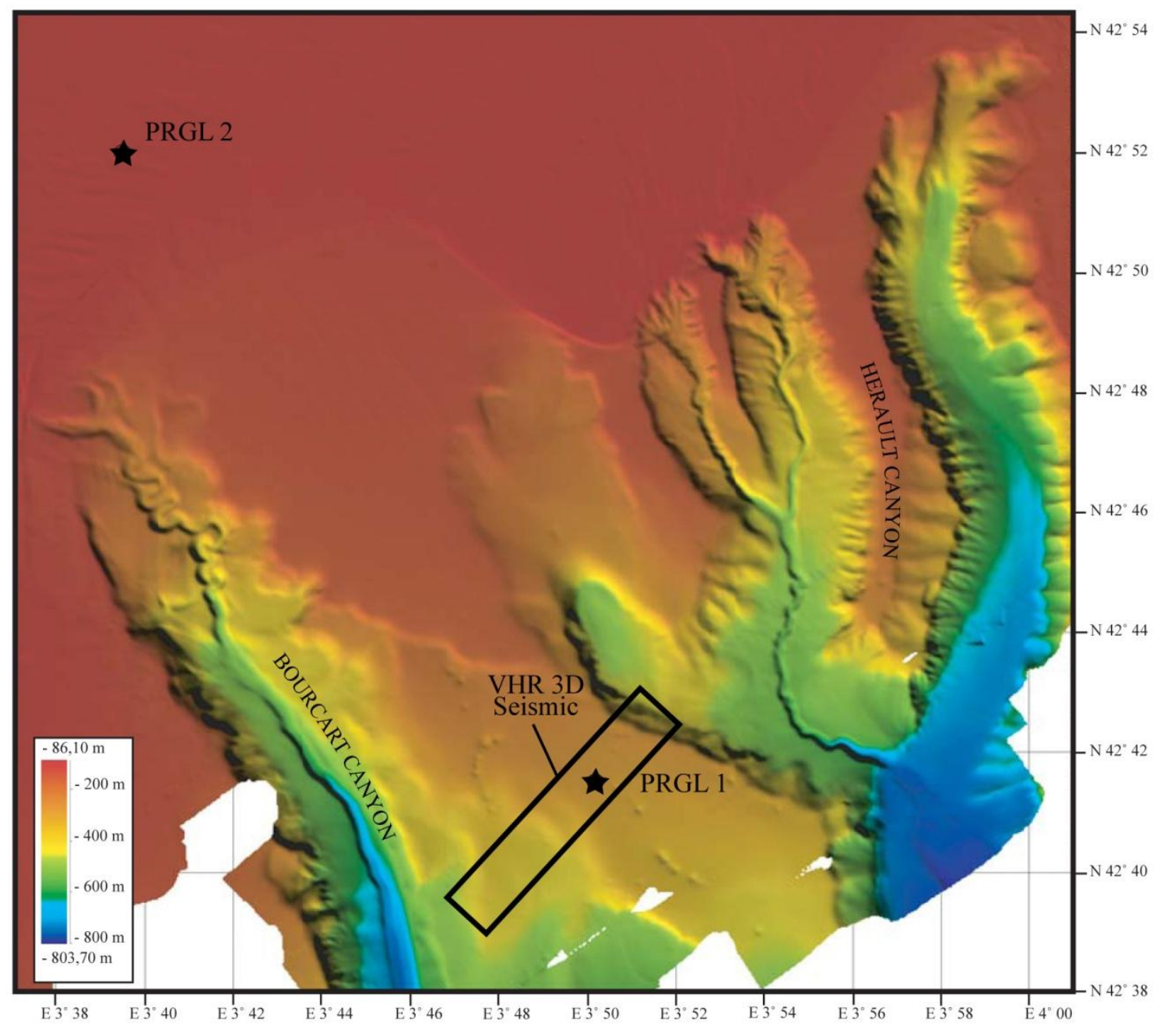

Fig. 2 


\section{A. Gay et al.}

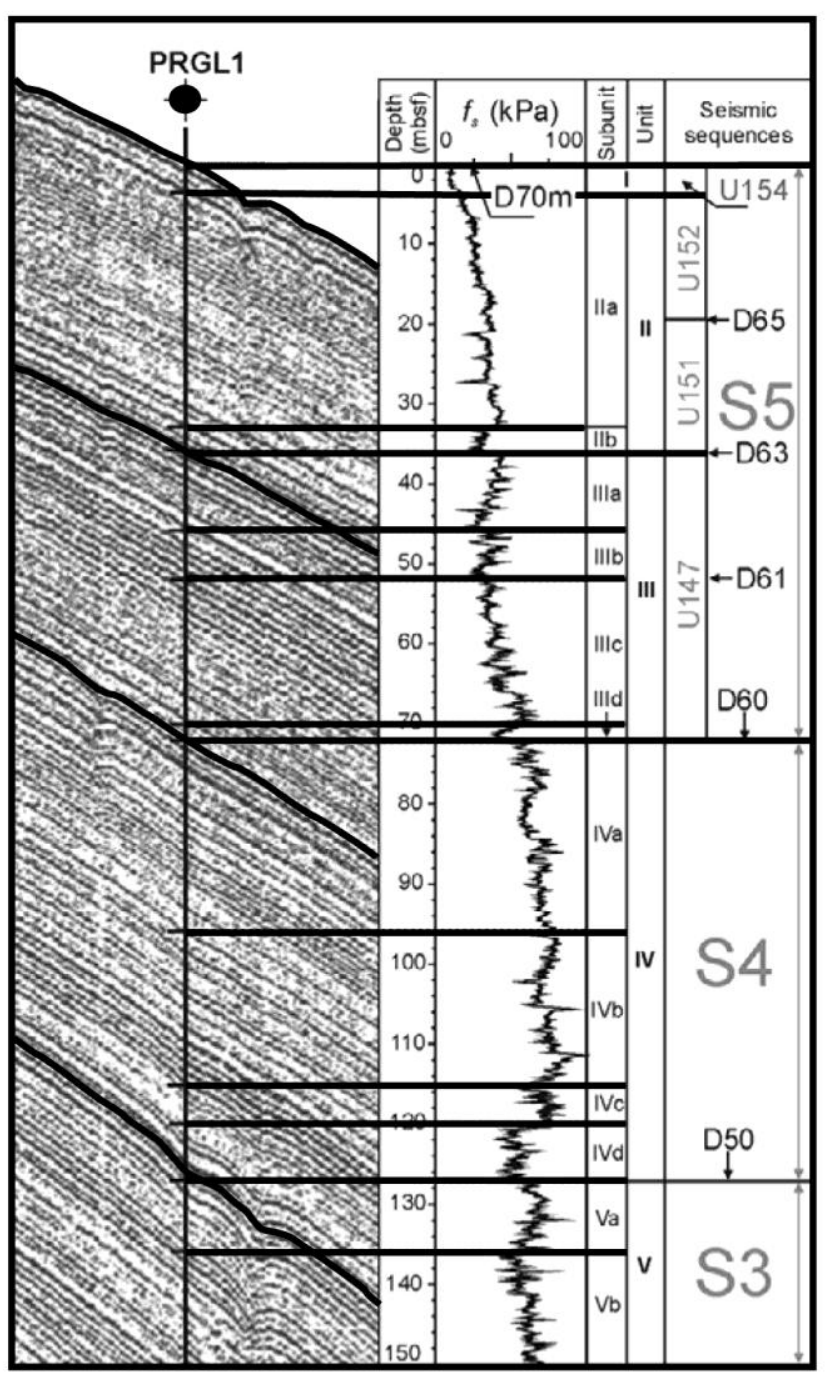

913

$914 \quad$ Fig. 3

915 


\section{A. Gay et al.}

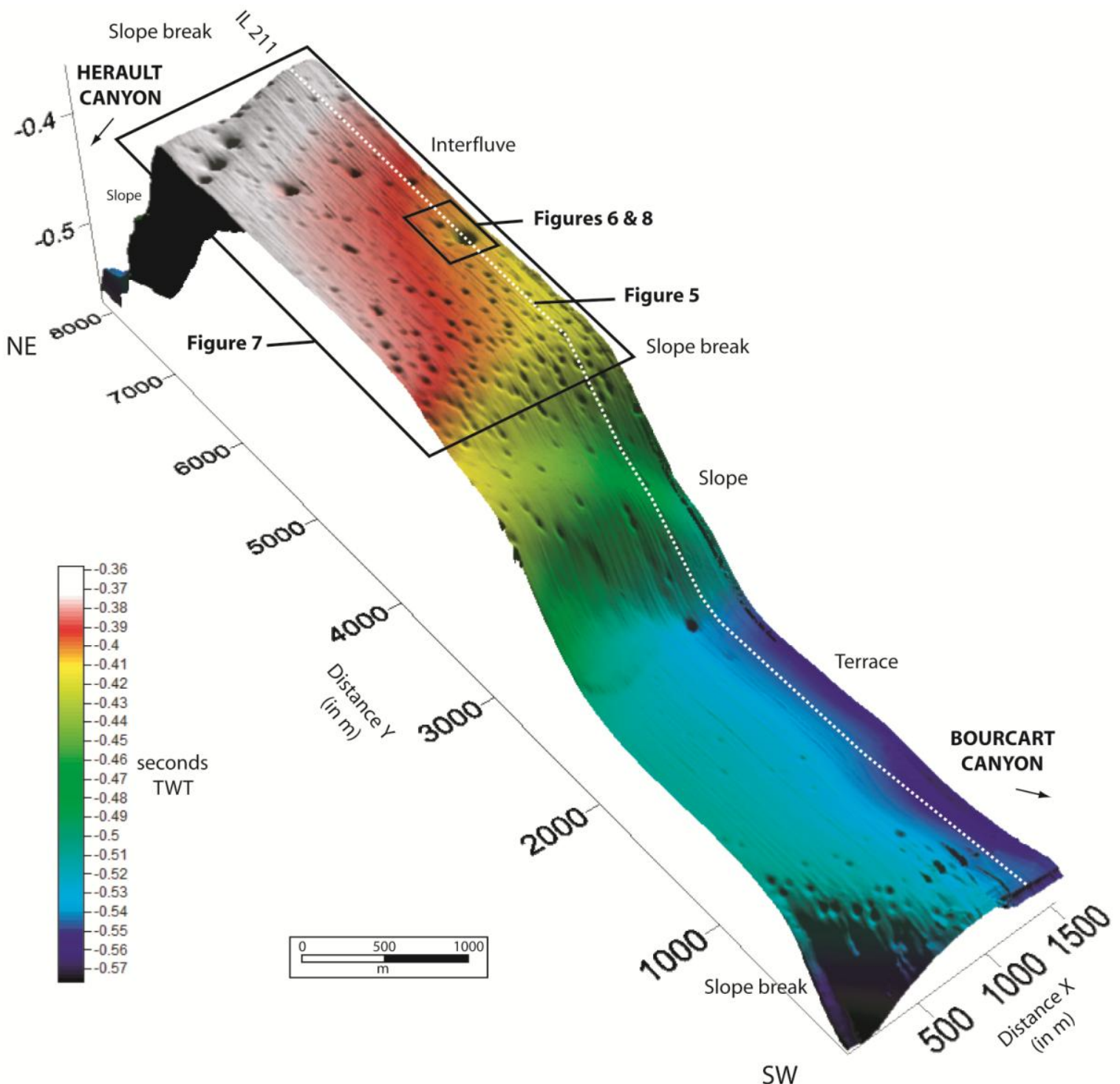

$917 \quad$ Fig. 4 
A. Gay et al.

919

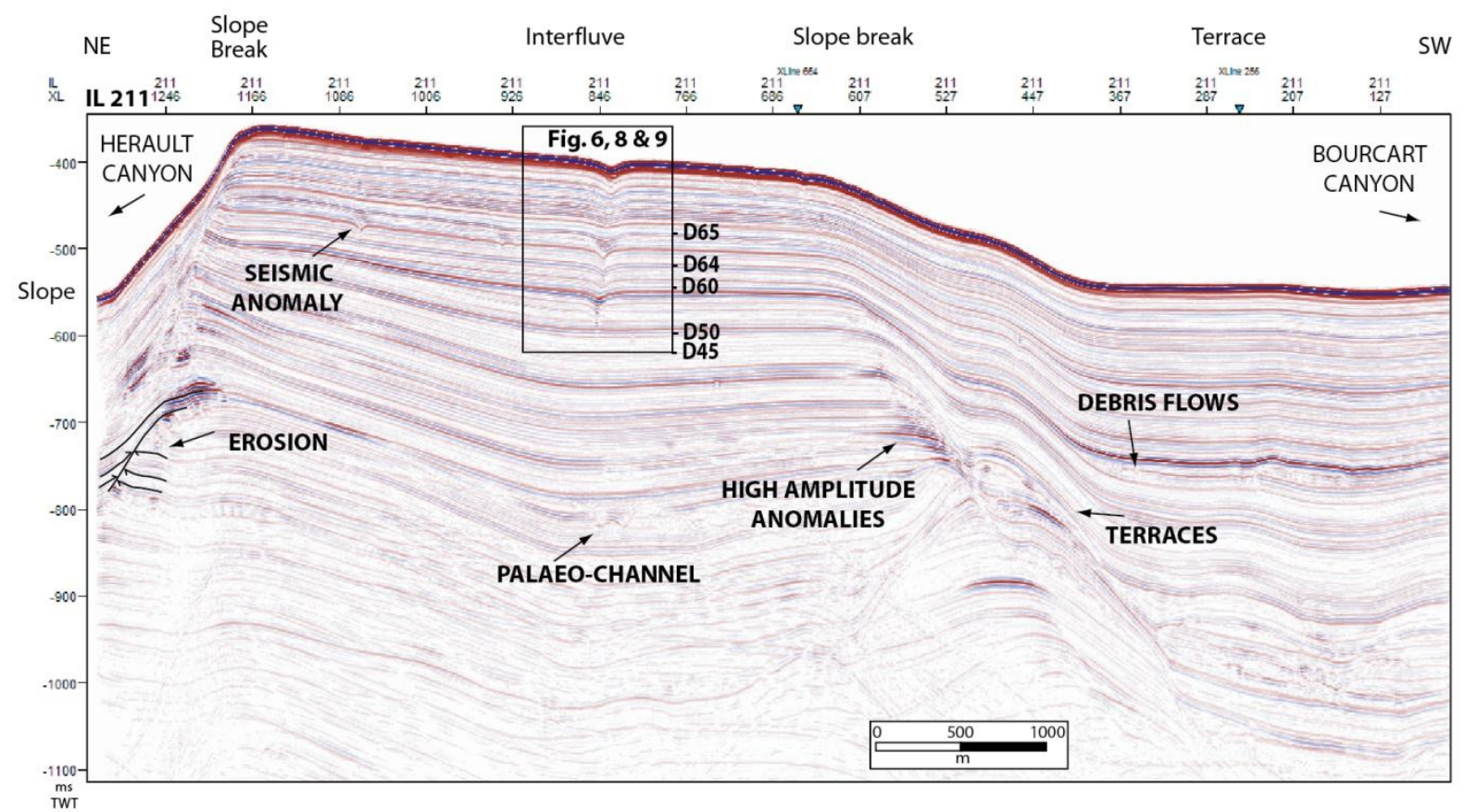

$920 \quad$ Fig. 5

921

922

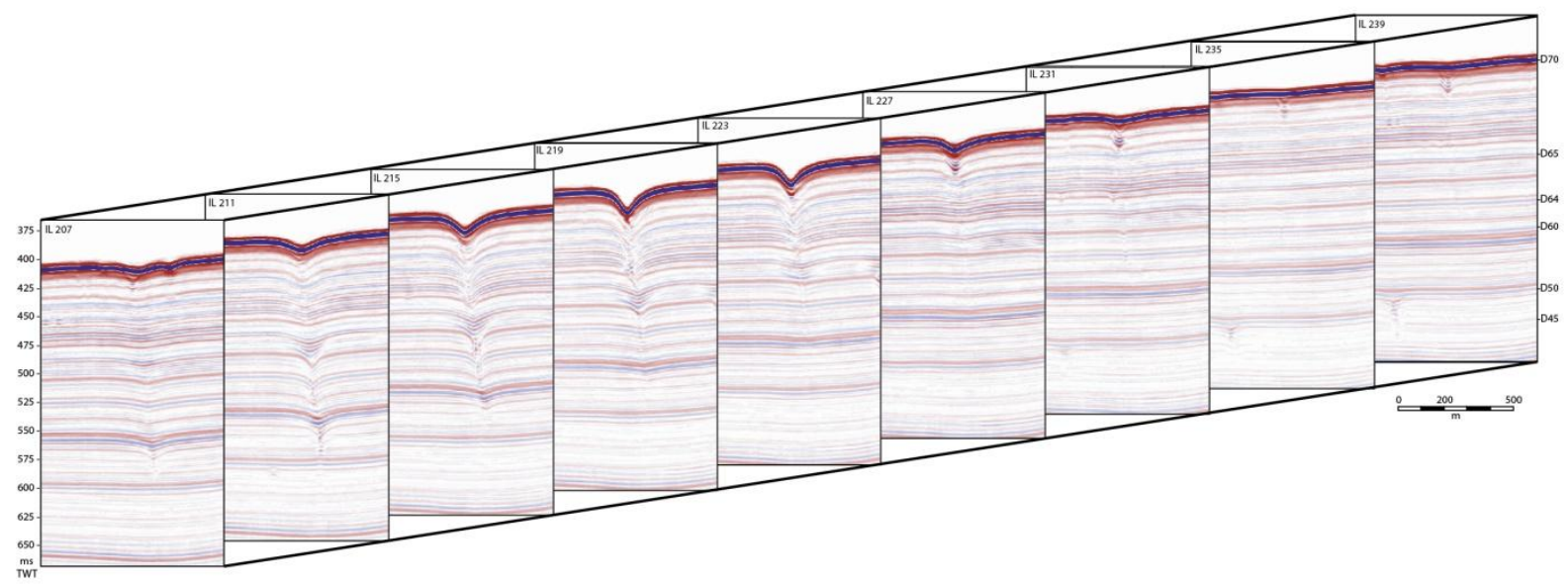

$923 \quad$ Fig. 6

924 

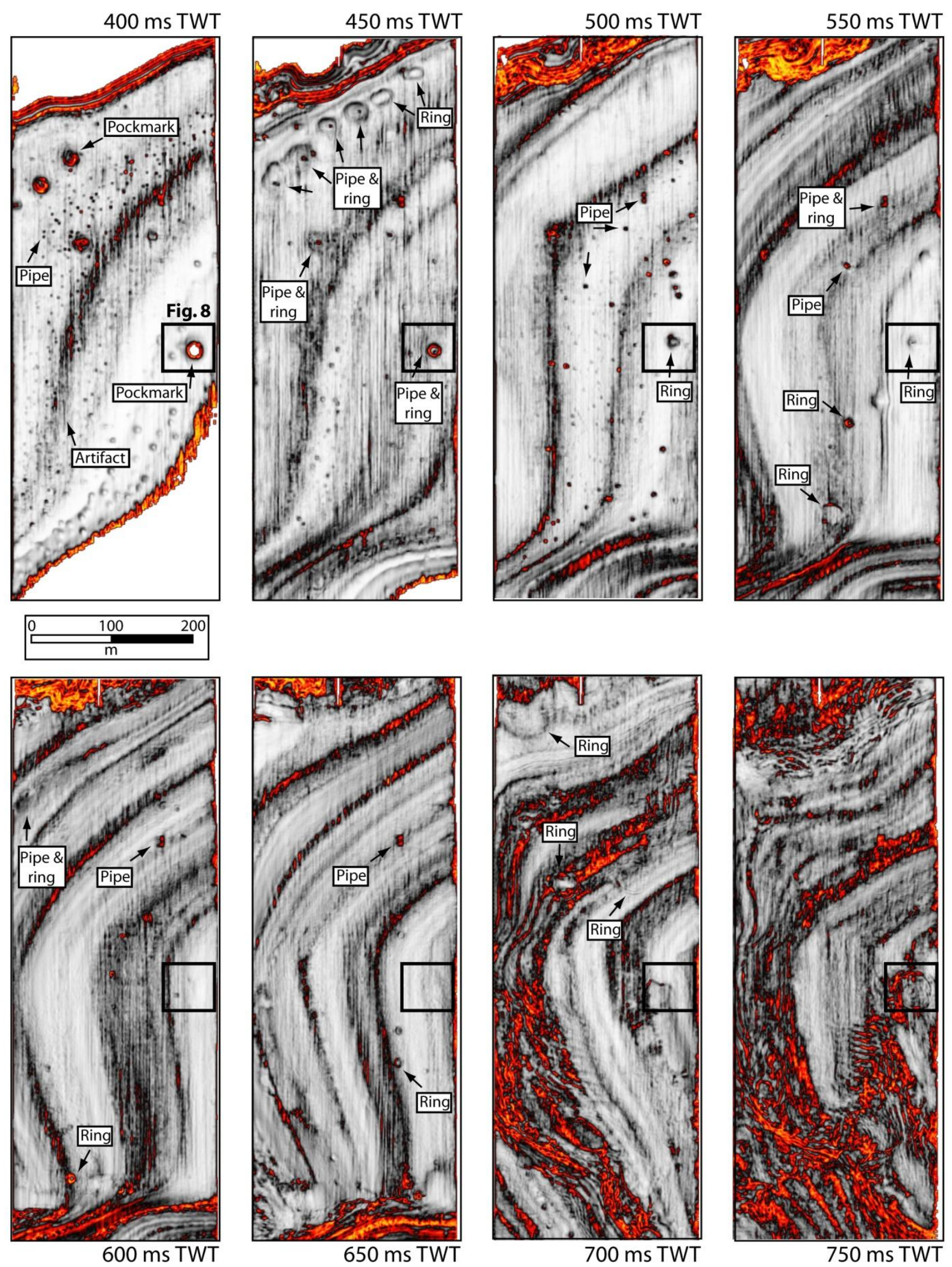

Fig. 7 


\section{A. Gay et al.}

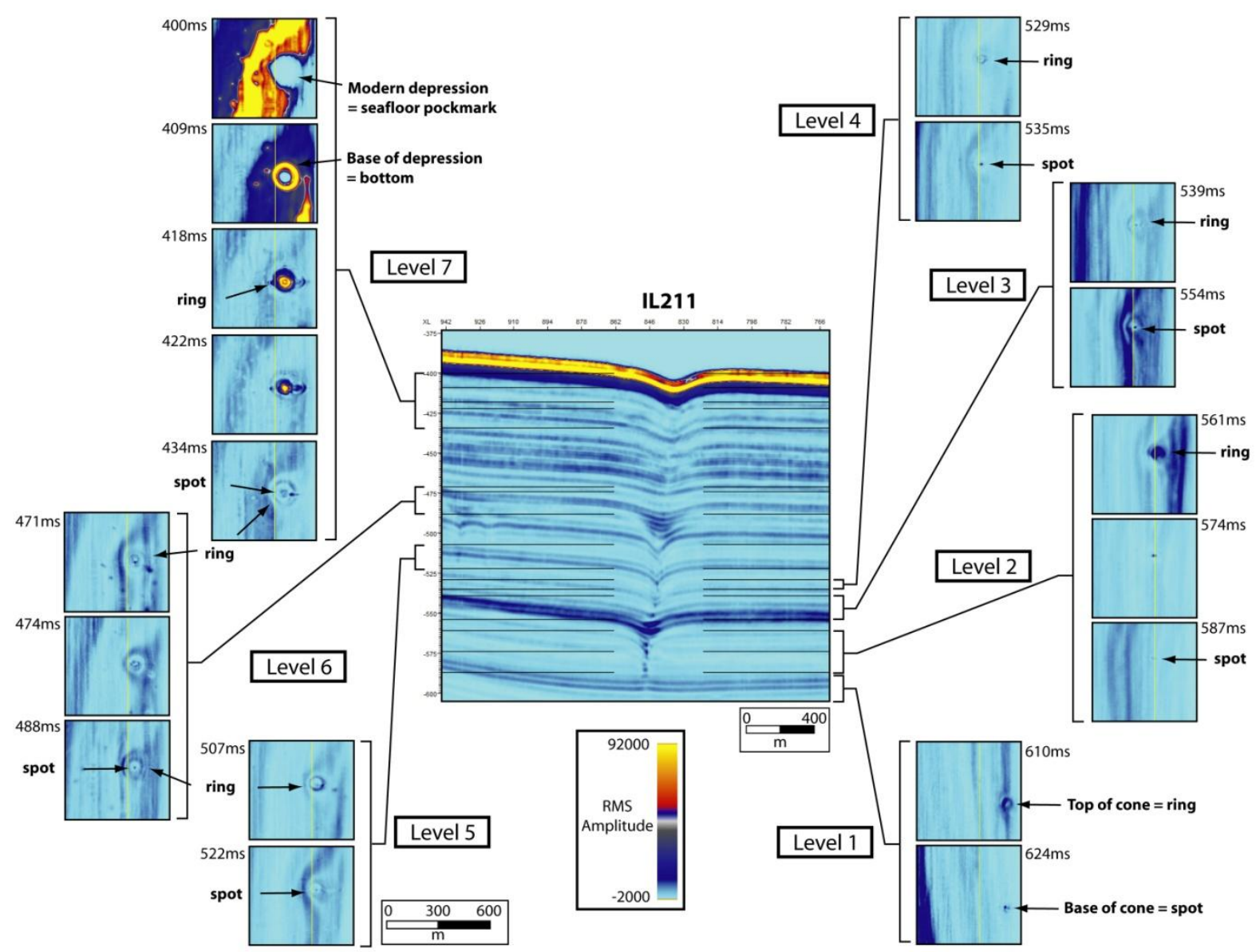

Fig. 8

930
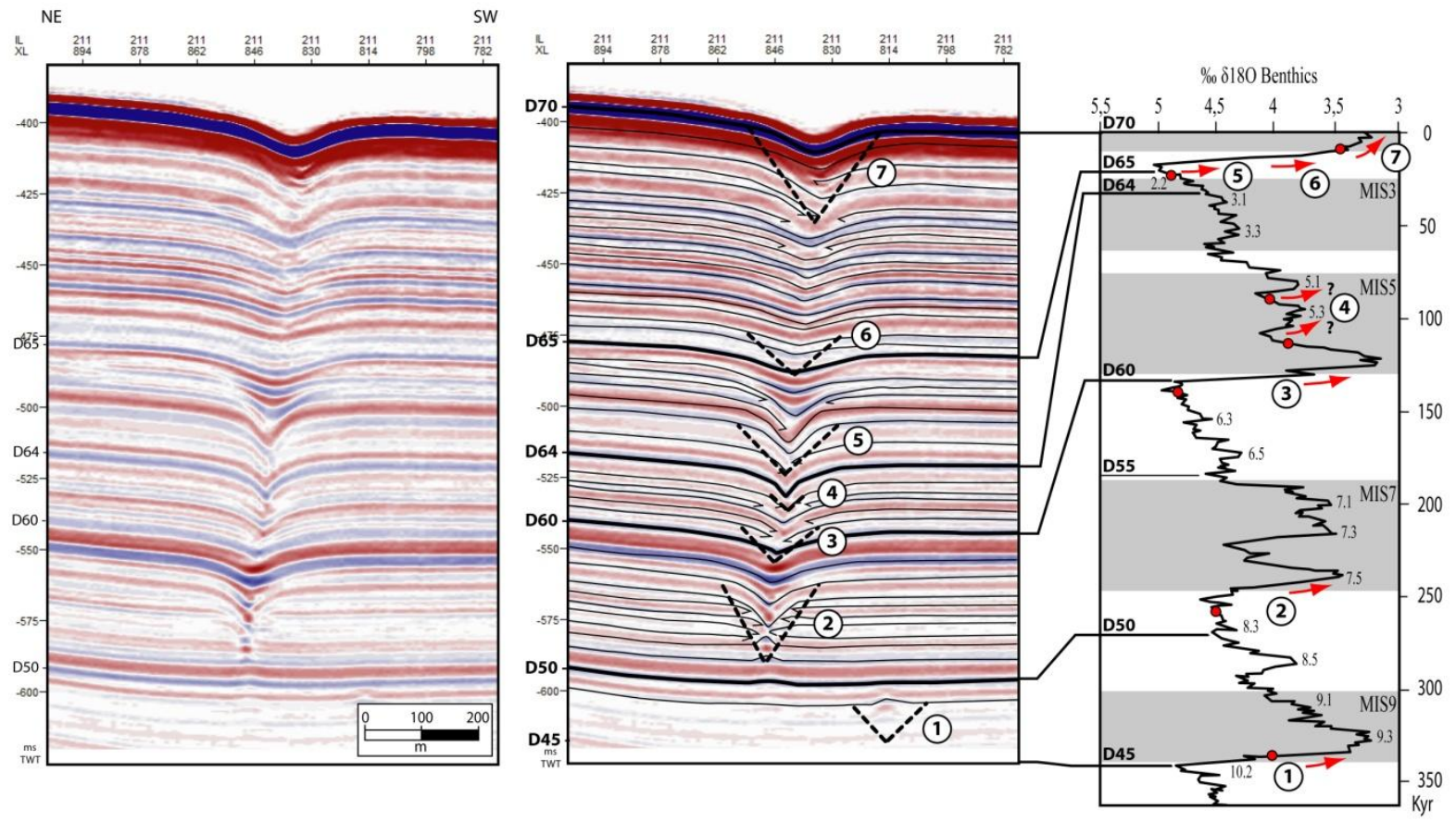

Fig. 9 
A. Gay et al.

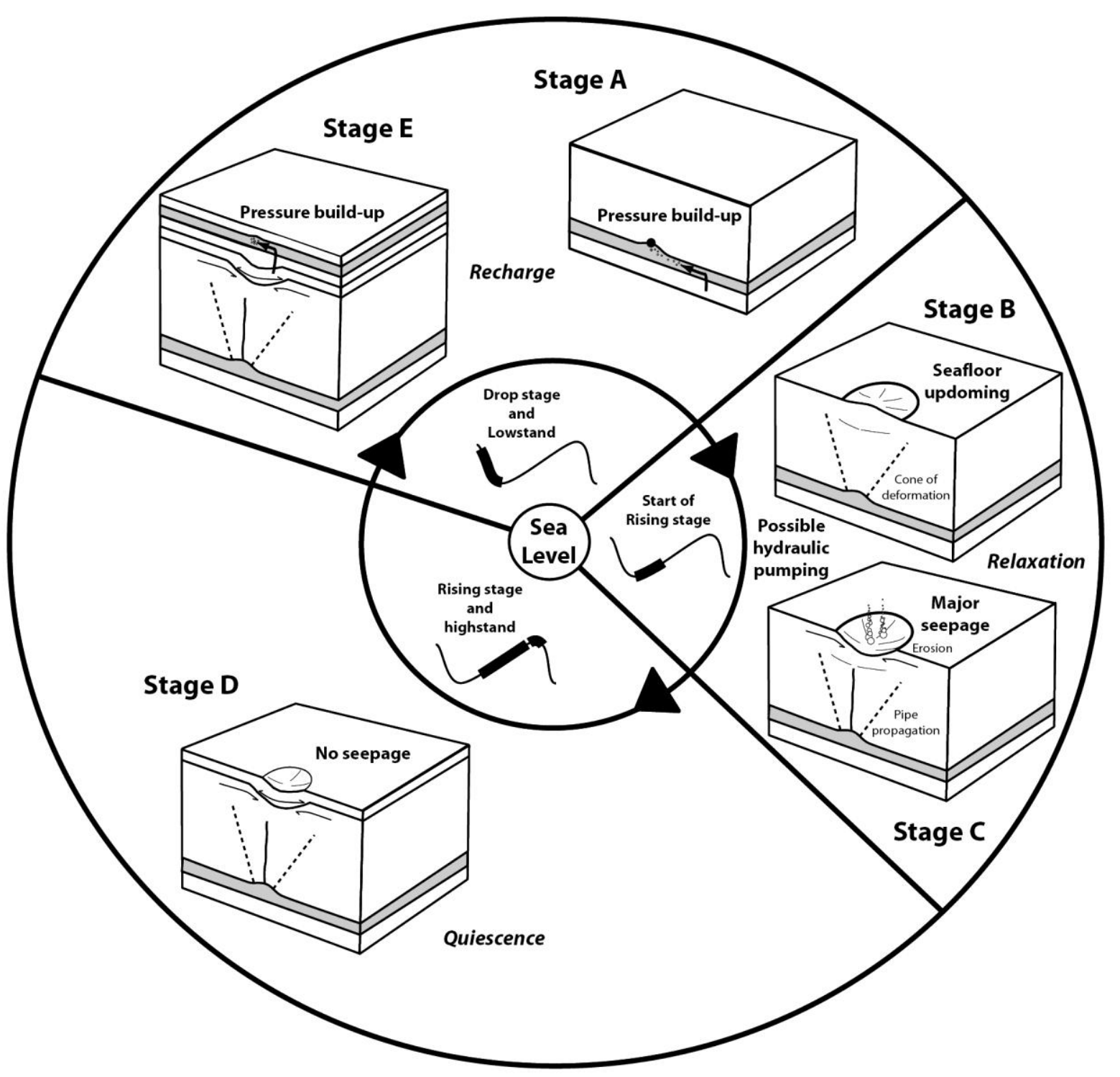

933

934 Fig. 10 